University of Nebraska - Lincoln

DigitalCommons@University of Nebraska - Lincoln

\title{
DEVELOPMENT AND EVALUATION OF BANKFULL HYDRAULIC GEOMETRY RELATIONSHIPS FOR THE PHYSIOGRAPHIC REGIONS OF THE UNITED STATES
}

\author{
Katrin Bieger \\ Blackland Research and Extension Center, Texas A\&M, kbieger@brc.tamus.edu \\ Hendrik Rathjens \\ Earth, Atmospheric, and Planetary Sciences, Purdue University \\ Peter M. Allen \\ Department of Geology, Baylor University \\ Jeffrey G. Arnold \\ USDA-ARS Grassland, Soil and Water Research Laboratory, jeff.arnold@ars.usda.gov
}

Follow this and additional works at: https://digitalcommons.unl.edu/usdaarsfacpub

Part of the Geology Commons, and the Geomorphology Commons

\begin{abstract}
Bieger, Katrin; Rathjens, Hendrik; Allen, Peter M.; and Arnold, Jeffrey G., "DEVELOPMENT AND EVALUATION OF BANKFULL HYDRAULIC GEOMETRY RELATIONSHIPS FOR THE PHYSIOGRAPHIC REGIONS OF THE UNITED STATES" (2015). Publications from USDA-ARS / UNL Faculty. 1515. https://digitalcommons.unl.edu/usdaarsfacpub/1515
\end{abstract}

This Article is brought to you for free and open access by the U.S. Department of Agriculture: Agricultural Research Service, Lincoln, Nebraska at DigitalCommons@University of Nebraska - Lincoln. It has been accepted for inclusion in Publications from USDA-ARS / UNL Faculty by an authorized administrator of DigitalCommons@University of Nebraska - Lincoln. 


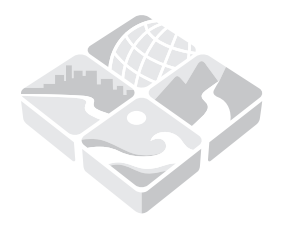

\title{
DEVELOPMENT AND EVALUATION OF BANKFULL HYDRAULIC GEOMETRY RELATIONSHIPS FOR THE PHYSIOGRAPHIC REGIONS OF THE UNITED STATES ${ }^{1}$
}

\author{
Katrin Bieger, Hendrik Rathjens, Peter M. Allen, and Jeffrey G. Arnold ${ }^{2}$
}

\begin{abstract}
Bankfull hydraulic geometry relationships are used to estimate channel dimensions for streamflow simulation models, which require channel geometry data as input parameters. Often, one nationwide curve is used across the entire United States (U.S.) (e.g., in Soil and Water Assessment Tool), even though studies have shown that the use of regional curves can improve the reliability of predictions considerably. In this study, regional regression equations predicting bankfull width, depth, and cross-sectional area as a function of drainage area are developed for the Physiographic Divisions and Provinces of the U.S. and compared to a nationwide equation. Results show that the regional curves at division level are more reliable than the nationwide curve. Reliability of the curves depends largely on the number of observations per region and how well the sample represents the population. Regional regression equations at province level yield even better results than the division-level models, but because of small sample sizes, the development of meaningful regression models is not possible in some provinces. Results also show that drainage area is a less reliable predictor of bankfull channel dimensions than bankfull discharge. It is likely that the regional curves can be improved using multiple regression models to incorporate additional explanatory variables.
\end{abstract}

(KEY TERMS: streams; fluvial geomorphology; bankfull discharge; nationwide and regional regression equations; hydrologic modeling.)

Bieger, Katrin, Hendrik Rathjens, Peter M. Allen, and Jeffrey G. Arnold, 2015. Development and Evaluation of Bankfull Hydraulic Geometry Relationships for the Physiographic Regions of the United States. Journal of the American Water Resources Association (JAWRA) 1-17. DOI: 10.1111/jawr.12282

\section{INTRODUCTION}

Attempts to predict processes at regional scales are often limited by the spatial information that is available. Obtaining representative channel geometries is crucial for improving the predictive capabilities of watershed models. Many hydrologic models, such as the Soil and Water Assessment Tool (SWAT) (Arnold et al., 1998) and Hydrologic Simulation Program-For- tran (HSPF) (Bicknell et al., 1997), require channel dimensions, e.g., bankfull width, depth, and cross-sectional area, as input parameters (Ames et al., 2009). Hydraulic geometry (HG) relationships are frequently used not only for stream classification and natural channel design but also to provide such data for hydrologic modeling studies.

The concept of HG was first introduced by Leopold and Maddock (1953) to describe the dependency of channel dimensions on discharge within specific river

\footnotetext{
${ }^{1}$ Paper No. JAWRA-13-0228-P of the Journal of the American Water Resources Association (JAWRA). Received October 21, 2013; accepted November 28, 2014. (C) 2015 American Water Resources Association. Discussions are open until six months from print publication.

${ }^{2}$ Postdoctoral Research Associate (Bieger), Blackland Research and Extension Center, Texas A\&M AgriLife, 720 E. Blackland Road, Temple, Texas 76502; Postdoctoral Research Associate (Rathjens), Earth, Atmospheric, and Planetary Sciences, Purdue University, West Lafayette, Indiana 47907; Professor (Allen), Department of Geology, Baylor University, Waco, Texas 76798; and Research Agricultural Engineer (Arnold), Grassland, Soil and Water Research Laboratory, USDA-ARS, Temple, Texas 76502 (E-Mail/Bieger: kbieger@brc.tamus.edu).
} 
basins. Based on a study of gauging station records for 20 large rivers in the Great Plains and in the southwestern United States (U.S.), they expressed the relationship between average annual discharge and channel width, depth, and flow velocity in terms of simple power functions (Dingman, 2007). Bankfull HG relationships use bankfull discharge instead of average annual discharge as the independent variable to predict channel dimensions (Leopold et al., 1964). Bankfull discharge is a deterministic discharge representing the channel-forming discharge in a stream (Copeland et al., 2000). It is defined as the highest flow a channel can convey before it starts to spill onto its floodplain (Leopold et al., 1964) and can be identified in the field using physical indicators (Mulvihill and Baldigo, 2012).

As the use of discharge as the independent variable limits the applicability of $\mathrm{HG}$ equations to gauged stream reaches (Ames et al., 2009), Dunne and Leopold (1978) introduced the use of drainage area as a surrogate for discharge. Acquiring complete channel geometry measurements can be time consuming and cost prohibitive, while bankfull HG curves can provide the channel dimensions that are required by hydrologic models by using only the drainage area, which can be derived from readily available Digital Elevation Models (Cinotto, 2003; Chaplin, 2005; Faustini et al., 2009). In addition, Dunne and Leopold (1978) developed HG relationships on a regional level. Based on the assumption that within a physiographic region the geology, soil, climate, and hydrology are similar, they expected HG relationships to be similar within these definable regions. These regional curves illustrate channel dimensions as a function of drainage area on log-log plots.

Regional HG curves such as those developed by Dunne and Leopold (1978) were never widely applied for hydrologic models as they lacked applicable equations for larger geographic use. Allen et al. (1994) pointed out that measured channel dimensions required to develop such equations are usually not available over large geographic areas. Nevertheless, the data presented by Dunne and Leopold (1978) indicated major regional differences in channel dimensions, which justifies recent trends toward more detailed regional curves in order to more accurately assess HG in areas of varying physiography and climate. Recently, more localized HG curves have been developed for many areas across the country to address classification and natural channel design restoration needs (Mulvihill and Baldigo, 2012). An increasing use of bankfull HG relationships for the design of stream restoration projects has resulted in a number of studies carried out all over the U.S. (Harman et al., 1999; Smith and Turrini-Smith, 1999;
Harman et al., 2000; Castro and Jackson, 2001; White, 2001; McCandless and Everett, 2002; Cinotto, 2003; McCandless, 2003a, b; Sweet and Geratz, 2003; Emmert, 2004; Messinger and Wiley, 2004; Powell et al., 2004; Babbit, 2005; Keaton et al., 2005; Mohamoud and Parmar, 2006; Mulvihill et al., 2006; Vesely et al., 2008; Padmanabhan and Johnson, 2010).

The studies listed above provide a useful dataset to develop regional bankfull $\mathrm{HG}$ equations that can be used in hydrologic models. Currently, many models use bankfull HG relationships that were developed for large geographic areas. For example, the SWAT (Arnold et al., 1998), which is also integrated in the environmental analysis system BASINS (Better Assessment Science Integrating Point and Nonpoint Sources) developed by the U.S. Environmental Protection Agency, uses nationwide equations to estimate bankfull channel width and depth (Raghavan Srinivasan, personal communication, 2014).

In this study, we hypothesize that regional equations provide more reliable predictions of bankfull channel dimensions than a nationwide curve and therefore should be used in hydrologic models to predict channel dimensions. Therefore, the objectives were to use a large database of bankfull HG data compiled from over 50 different publications (1) to develop bankfull HG relationships for the conterminous U.S. and for physiographic regions at different spatial levels, (2) to compare the regional regression equations and determine if they are more accurate than the nationwide equation, and (3) to assess the performance of drainage area as a surrogate for bankfull discharge.

\section{MATERIALS AND METHODS}

\section{Database}

We used a large dataset comprising bankfull HG data for sites in the conterminous U.S. published by almost 50 different authors over the past 50 years (Table 1). The original database compiled from these literature sources contained data for a total of 1,861 sites. However, the selected datasets were inconsistent in the number and type of variables they contained. Datasets were only considered suitable for analysis in this study when data on latitude and longitude, drainage area, and at least one of the variables bankfull width, depth, and cross-sectional area were available. Datasets that did not meet the above criteria were omitted from analysis. Also, no urban streams were included in the database. There 
TABLE 1. Sources of Bankfull Hydraulic Geometry Data Compiled in This Study.

\begin{tabular}{|c|c|c|}
\hline References & Number of Sites & States \\
\hline Andrews (1984) & 24 & Colorado \\
\hline Babbit (2005) & 10 & Tennessee \\
\hline Brockman (2010) & 29 & Kentucky \\
\hline Castro and Jackson (2001) & 75 & Idaho, Oregon, Washington \\
\hline Chaplin (2005) & 52 & Maryland, Pennsylvania \\
\hline Cinotto (2003) & 14 & Maryland, Pennsylvania \\
\hline Doll et al. (2003) & 16 & North Carolina \\
\hline Dudley (2004) & 10 & Maine \\
\hline Dutnell (2000) & 48 & Kansas, Missouri, Oklahoma, Texas \\
\hline Eash (1993) & 111 & Iowa \\
\hline Elliott and Cartier (1986) & 18 & Colorado \\
\hline Emmett (1975) & 39 & Idaho \\
\hline Harman et al. (1999) & 13 & North Carolina \\
\hline Harman et al. (2000) & 14 & North Carolina \\
\hline Haucke and Clancy (2011) & 12 & Wisconsin \\
\hline Howell (2009) & 8 & California \\
\hline Jaquith and Kline (2006) & 20 & Vermont \\
\hline $\begin{array}{l}\text { Johnson and Padmanabhan (2010); } \\
\text { Padmanabhan and Johnson (2010) }\end{array}$ & 22 & Minnesota, North Dakota \\
\hline Keaton et al. (2005) & 41 & Maryland, Virginia, West Virginia \\
\hline King et al. (2004) & 33 & Idaho \\
\hline Krstolic and Chaplin (2007) & 8 & Maryland, Virginia \\
\hline Lawlor (2004) & 41 & Montana \\
\hline Leopold and Wolman (1957) & 19 & Maryland, Montana, Nebraska, Wyoming \\
\hline Lotspeich (2009) & 17 & Virginia \\
\hline Mater et al. (2009) & 20 & Kentucky \\
\hline McCandless (2003a) & 14 & Maryland, Pennsylvania \\
\hline McCandless (2003b) & 14 & Delaware, Maryland \\
\hline McCandless and Everett (2002) & 25 & Maryland \\
\hline McPherson (2011) & 16 & Tennessee \\
\hline Messinger (2009) & 37 & West Virginia \\
\hline Metcalf (2004) & 26 & Alabama, Florida, Georgia \\
\hline Mistak and Stille (2008) & 5 & Michigan, Wisconsin \\
\hline Moody et al. (2003) & 183 & Arizona, New Mexico, Navajo Nation \\
\hline Mulvihill and Baldigo (2007) & 12 & New York \\
\hline Mulvihill et al. (2005) & 14 & New York \\
\hline Mulvihill et al. (2006) & 10 & New York \\
\hline Mulvihill et al. (2007) & 16 & New York \\
\hline $\begin{array}{l}\text { Miller and Davis (2003); } \\
\text { Mulvihill et al. (2009) }\end{array}$ & 14 & New York \\
\hline Osterkamp et al. (1982) & 17 & Kansas \\
\hline Parola et al. (2005a) & 13 & Kentucky \\
\hline Parola et al. (2005b) & 5 & Kentucky \\
\hline Parola et al. (2007) & 20 & Kentucky \\
\hline Parrett et al. (1983) & 209 & Montana \\
\hline Pruitt (2001) & 6 & Georgia \\
\hline Pugh et al. (2008) & 9 & Arkansas \\
\hline Rachol and Boley-Morse (2009) & 40 & Michigan \\
\hline Sherwood and Huitger (2005) & 50 & Ohio \\
\hline Sweet and Geratz (2003) & 24 & North Carolina \\
\hline Vesely et al. (2008) & 26 & Kentucky \\
\hline Westergard et al. (2005) & 16 & New York \\
\hline Williams (1978) & 51 & $\begin{array}{l}\text { Arizona, Colorado, Kentucky, Massachusetts, } \\
\text { New Mexico, North Dakota, Oregon, Pennsylvania, Tennessee, } \\
\text { Utah, West Virginia, Wisconsin, Wyoming }\end{array}$ \\
\hline
\end{tabular}

were a few sites where data from two different literature sources were available. In these cases, the more complete dataset was used for analysis while the other one was excluded.
According to McManamay et al. (2011), "regional frameworks inform management by relating spatial patterns to ecological and physical variables at the landscape scale." They conclude from their study 
examining different regional frameworks applied to hydrology that the development of regional frameworks is appropriate and useful. Simon et al. (2004) point out the importance of placing existing data in a conceptual and analytical framework so that they can be used at ungauged sites. In this study, we used Physiographic Divisions and Provinces to stratify the available data. To distinguish different physiographic regions in the U.S., Fenneman and Johnson (1946) developed a classification system that is based on topography and geology. According to this system, the conterminous U.S. are divided into eight Physiographic Divisions: the Laurentian Upland, the Atlantic Plain, the Appalachian Highlands, the Interior Plains, the Interior Highlands, the Rocky Mountain System, the Intermontane Plateau, and the Pacific Mountain System. Each Physiographic Division is subdivided into Physiographic Provinces and Sections. Even though within each of the regions, there is a range of stream types, gross characteristics of the streams can be summarized and stream processes can be investigated broadly (Johnson, 2006). Johnson and Fecko (2008) used Physiographic Provinces in the Eastern U.S. as a regional framework for developing channel geometry equations and concluded that at a large scale they provide appropriate boundaries. Moyer and Bennett (2007) developed separate bankfull HG relationships for four Physiographic Provinces in the Chesapeake Bay Watershed and obtained satisfactory simulation results when using the estimated channel dimensions as input data for the model HSPF.

After exclusion of duplicate datasets and datasets that were not suitable for analysis because of a lack of critical data, the database contained a total of 1,310 sites. However, there is not necessarily data available for all the variables used for analysis at all sites. Also, the number of datasets varies considerably among the eight Physiographic Divisions. Table 2 lists the number of sites with data available for the variables drainage area and bankfull discharge, width, depth, and cross-sectional area per Physiographic Division and for the conterminous U.S. The database is available for download under http:// swat.tamu.edu/publications/.

Summarizing, the data required for this assessment are available for a relatively large number of sites in the Appalachian Highlands (387), the Interior Plains (425), and the Rocky Mountain System (288) (Figure 1 and Table 2). Even though the largest number of sites is available for the Interior Plains, due to the vast extent of this Physiographic Division there are large spatial gaps in the data. In the Appalachian Highlands and the Rocky Mountain System, the sites are relatively well distributed and cover almost the entire region (Figure 1). Data are available for considerably fewer sites in the Atlantic Plain (61), the Intermontane Plateau (88), the Pacific Mountain System (48), and especially the Laurentian Upland (6) and the Interior Highlands (7), so there are considerable spatial gaps in the data. Even though the latter two are very small regions and therefore spatial gaps in the data are not larger than in the former three regions, the sites are strongly clustered, so only a small fraction of the area of each region is represented by the sample sites (Figure 1 and Table 2).

For all five variables (drainage area and bankfull discharge, width, depth, and cross-sectional area), the largest range of values occurs in the Interior Plains and the smallest in the Laurentian Upland. This is partly an effect of sample size, but the broad geographic extent of the Interior Plains spanning a large climatic gradient probably also contributes to the wide range of channel dimensions in this Physiographic Division. The second and third largest ranges of drainage areas occur in the Rocky Mountain System and in the Pacific Mountain System, while the remaining variables exhibit larger ranges in the Pacific Mountain System than in the Rocky Mountain System. The Intermontane Plateau, the Atlantic Plain, the Appalachian Highlands, and the Interior Highlands rank fourth, fifth, sixth, and seventh with regard to the maximum range of drainage areas, while their ranks with regard to the ranges of bankfull discharge, width, depth, and cross-sectional area are highly variable (Table 2). Bankfull channel dimensions are generally greater in the Laurentian Upland, the Interior Highlands, and the Pacific Mountain System than in the remaining Physiographic Divisions, which is most likely an artifact of sampling bias toward higher discharge streams.

\section{Regression Equations}

Linear regression models relating the independent variable of drainage area to the dependent variables of bankfull width, depth, and cross-sectional area were developed for the conterminous U.S. and for the Physiographic Divisions and Provinces. The regression equations express the mathematical relationships between log-transformed bankfull channel dimensions and drainage area and take the form

$$
y=a \cdot \mathrm{DA}^{b}
$$

where $y$ is the dependent variable (bankfull width $[\mathrm{m}]$, depth $[\mathrm{m}]$, or cross-sectional area $\left.\left[\mathrm{m}^{2}\right]\right)$, DA is the independent variable of drainage area, $a$ is a coefficient indicating the intercept of the regression line, and $b$ is an exponent representing the slope of the regression line. 
TABLE 2. Number of Sites with Available Data and the Range and Median of Drainage Area and Bankfull Discharge, Width, Depth, and Cross-Sectional Area per Physiographic Division.

\begin{tabular}{|c|c|c|c|c|c|}
\hline $\begin{array}{l}\text { Physiographic } \\
\text { Division }\end{array}$ & $\begin{array}{c}\text { Drainage } \\
\text { Area } \\
\left(\mathbf{k m}^{2}\right)\end{array}$ & $\begin{array}{c}\text { Bankfull } \\
\text { Discharge } \\
\left(\mathrm{m}^{3} / \mathrm{s}\right)\end{array}$ & $\begin{array}{l}\text { Bankfull } \\
\text { Width } \\
\text { (m) }\end{array}$ & $\begin{array}{l}\text { Bankfull } \\
\text { Depth } \\
\text { (m) }\end{array}$ & $\begin{array}{c}\text { Bankfull } \\
\text { Cross-Sectional } \\
\text { Area }\left(\mathbf{m}^{2}\right)\end{array}$ \\
\hline \multicolumn{6}{|l|}{ LUP } \\
\hline No. of sites & 6 & 6 & 6 & 6 & 6 \\
\hline Range & $43-948$ & $1.4-45$ & $14-41$ & $0.6-1.7$ & $8.2-69$ \\
\hline Median & 384 & 24 & 27 & 1.0 & 25 \\
\hline \multicolumn{6}{|l|}{ APL } \\
\hline No. of sites & 61 & 61 & 61 & 61 & 61 \\
\hline Range & $0.8-2,815$ & $0.2-75$ & $2.3-46$ & $0.2-3.1$ & $0.5-108$ \\
\hline Median & 116 & 6 & 11 & 1.0 & 10 \\
\hline \multicolumn{6}{|l|}{ AHI } \\
\hline No. of sites & 387 & 374 & 377 & 377 & 377 \\
\hline Range & $0.2-2,435$ & $0.2-304$ & $1.7-98$ & $0.2-2.8$ & $0.3-193$ \\
\hline Median & 81 & 24 & 18 & 0.9 & 17 \\
\hline \multicolumn{6}{|l|}{ IPL } \\
\hline No. of sites & 425 & 210 & 414 & 394 & 216 \\
\hline Range & $0.5-155,213$ & $0.3-1,182$ & $0.8-274$ & $0.1-5.2$ & $0.2-1,705$ \\
\hline Median & 254 & 14 & 17 & 1.1 & 15 \\
\hline \multicolumn{6}{|l|}{ IHI } \\
\hline No. of sites & 7 & 5 & 7 & 7 & 7 \\
\hline Range & $78-2,484$ & $48-308$ & $33-76$ & $0.7-3.0$ & $28-196$ \\
\hline Median & 344 & 103 & 52 & 1.3 & 65 \\
\hline \multicolumn{6}{|l|}{ RMS } \\
\hline No. of sites & 288 & 160 & 278 & 273 & 122 \\
\hline Range & $0.4-25,201$ & $0.2-534$ & $1.3-99$ & $0.1-3.7$ & $0.2-243$ \\
\hline Median & 144 & 8 & 10 & 0.7 & 5 \\
\hline \multicolumn{6}{|l|}{ IMP } \\
\hline No. of sites & 88 & 79 & 88 & 88 & 88 \\
\hline Range & $9.4-19,632$ & $0.03-333$ & $1.3-87$ & $0.03-2.4$ & $0.1-161$ \\
\hline Median & 607 & 26 & 19 & 0.7 & 12 \\
\hline \multicolumn{6}{|l|}{ PMS } \\
\hline No. of sites & 48 & 48 & 48 & 48 & 48 \\
\hline Range & $16-20,927$ & $5.2-1,123$ & 7.3-183 & $0.5-5.1$ & $8.7-907$ \\
\hline Median & 778 & 114 & 41 & 1.8 & 67 \\
\hline \multicolumn{6}{|l|}{ USA } \\
\hline No. of sites & 1,310 & 943 & 1,279 & 1,254 & 925 \\
\hline Range & $0.2-155,213$ & $0.03-1,182$ & $0.8-274$ & $0.03-5.2$ & $0.1-1,705$ \\
\hline Median & 155 & 17 & 16 & 0.9 & 15 \\
\hline
\end{tabular}

Note: LUP, Laurentian Upland; APL, Atlantic Plain; AHI, Appalachian Highlands; IPL, Interior Plains; IHI, Interior Highlands; RMS, Rocky Mountain System; IMP, Intermontane Plateau; PMS, Pacific Mountain System.

The values of the coefficient $a$ and the exponent $b$ were determined by least-squares regression analysis using the logarithms (base 10) of the empirical values of drainage area and bankfull width, depth, and cross-sectional area contained in the database. The logarithmic transformation allows the application of linear techniques even though many of the variables possess moderate positive skewness (Kolberg and Howard, 1995). In accordance with the use of log-transformed variables in the regression analysis, regional curves are illustrated on a log-log scale.

The reliability of the regression equations was analyzed using the coefficient of determination $\left(R^{2}\right)$ and the standard error of estimate (SEE). $R^{2}$ is a measure of the fit of the data to the regression line and indicates how well the independent variable accounts for the variability of the dependent variable. SEE is a measure of the precision of regression equation estimates and indicates how well predicted channel dimensions agree with those measured during field surveys. For log-transformed data, an SEE value of $x$ corresponds to a multiplicative SEE of $10^{x}$. Thus, if an HG equation for bankfull width has an SEE of 0.15 , then the back-transformed SEE is a multiplicative factor of $1.41\left(10^{0.15}\right)$. So for a predicted width of $10.0 \mathrm{~m}, \mathrm{a} \pm 1 \mathrm{SEE}$ range would be from $10 / 1.41$ to $10^{*} 1.41$, i.e., from 7.1 to $14.1 \mathrm{~m}$. To compare the performance of the nationwide and the regional models, the SEE values for the regional models were compared to the SEE values for the national model applied to the subset of sites within each region. 


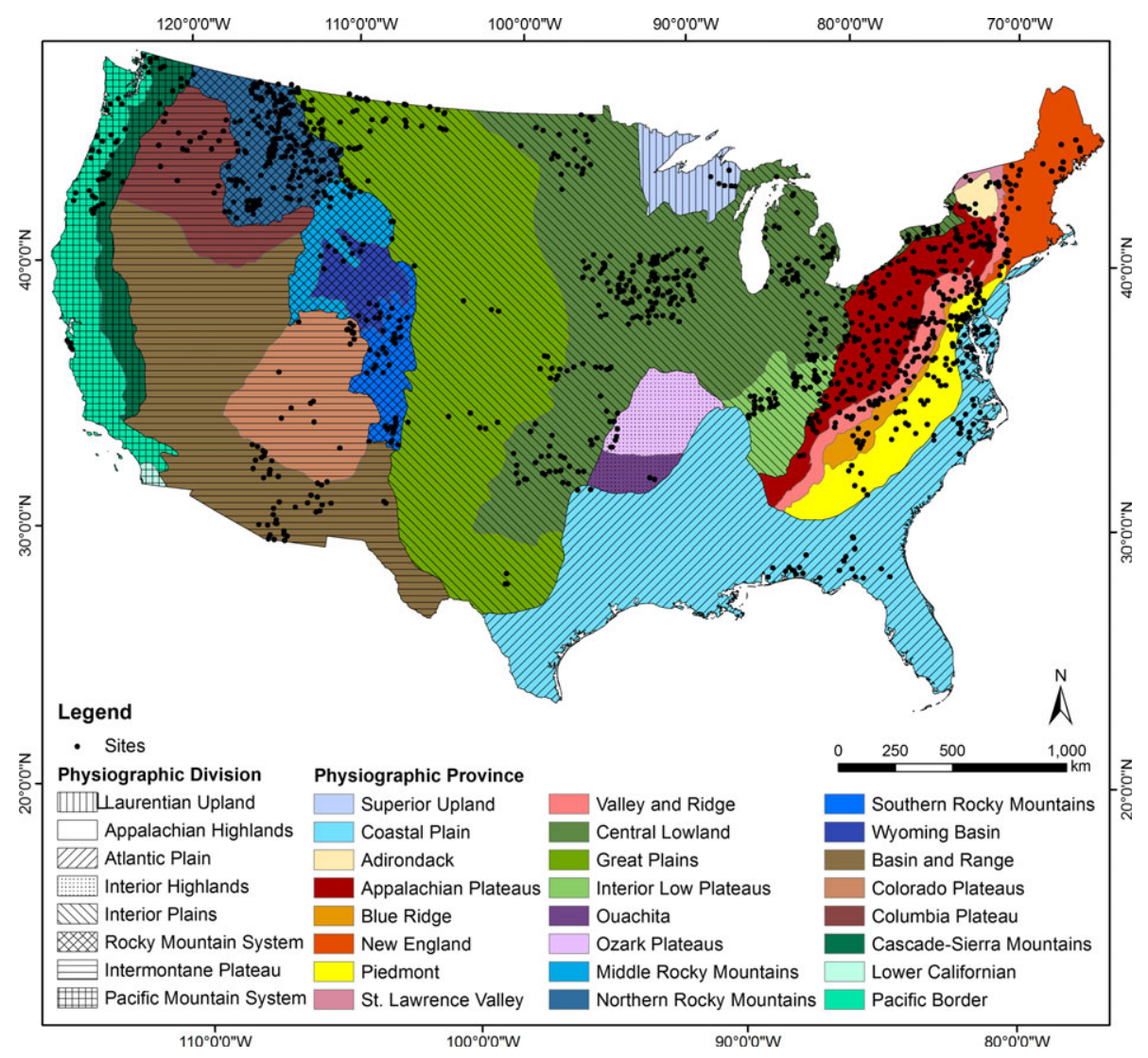

FIGURE 1. Bankfull Hydraulic Geometry Field Survey Sites and Physiographic Divisions of the U.S.

To find out if a finer stratification of the bankfull HG data based on Physiographic Provinces significantly improves the regression equations for bankfull width, depth, and cross-sectional area as a function of drainage area, the $R^{2}$, and SEE values for the Physiographic Provinces were compared to those for the corresponding Physiographic Division.

In addition, residuals plots and a table listing the standard errors of slope $\left(\mathrm{SE}_{S}\right)$ and intercept $\left(\mathrm{SE}_{I}\right)$ are available as an online supplement. $\mathrm{SE}_{S}$ and $\mathrm{SE}_{I}$ indicate the standard deviation of the slope and the intercept of a regression equation and should be smaller than slope and intercept themselves. Large $\mathrm{SE}_{S}$ and $\mathrm{SE}_{I}$ values indicate large, uncertainty in slope and intercept.

In this study, drainage area is used as a surrogate for discharge to enable the application of the regression equations not only to gaged but also to ungaged sites. Various studies have found a high correlation between drainage area and bankfull width, depth, and cross-sectional area (e.g., Dunne and Leopold, 1978; Harman et al., 1999; Smith and Turrini-Smith, 1999; Harman et al., 2000; Castro and Jackson, 2001; McCandless and Everett, 2002; Cinotto, 2003; McCandless, 2003a, b; Sweet and Geratz, 2003; Emmert, 2004; Powell et al., 2004; Babbit, 2005; Keaton et al., 2005). However, unlike discharge, drainage area is not directly responsible for shaping the channel, which makes the bankfull HG relationships based on drainage area less reliable than those based on discharge (Castro and Jackson, 2001; Johnson and Fecko, 2008). Due to differences in watershed shape, drainage pattern, slope, vegetation, land use, and management practices, magnitude and duration of bankfull discharges can vary in watersheds with similar drainage area (USDA-NRCS, 2007). To evaluate the performance of drainage area as a surrogate for bankfull discharge, an additional least-squares regression analysis was performed using bankfull discharge as the independent variable and $R^{2}$ and SEE values were compared.

\section{RESULTS}

\section{Regional Curves for the Eight Physiographic}

Divisions and the Conterminous U.S.

Visual examination of the regional curves relating bankfull width, depth, and cross-sectional area to 
drainage area reveals that there are large differences between some of the regions, while some regions are very similar to each other (Figure 2). In the following paragraphs, the description of results follows the order (1) width, (2) depth, and (3) cross-sectional area, even though in Figure 2 the regional curves for width and depth are plotted below those for crosssectional area to be comparable to the original plot by Dunne and Leopold (1978, p. 615) showing regional curves for four regions in the U.S.

With regard to bankfull width, the regional curves for the Atlantic Plain and the Interior Plains are very similar to the nationwide curve, whereas the regional curves for the Rocky Mountain System and the Intermontane Plateau plot below the nationwide curve, indicating that bankfull width in these Physiographic Divisions is generally smaller for a given drainage area than the nationwide average. The regional curves for the Laurentian Upland, the Appalachian Highlands, the Interior Highlands, and the Pacific Mountain System plot above the nationwide curve, indicating that bankfull width in these Physiographic Divisions is generally greater than the nationwide average for a given drainage area. The curve for the Interior Highlands, in particular, plots well above the nationwide curve and also is considerably flatter, indicating that bankfull width for streams in this Physiographic Division is considerably larger than the nationwide average for watersheds with drainage areas of about $100 \mathrm{~km}^{2}$, although the difference becomes smaller with increasing watershed size. However, due to the small sample size, the curve is not necessarily representative of the entire Physiographic Division. The curve for the Laurentian Upland is also slightly flatter than the nationwide curve, whereas the curves for the Appalachian Highlands, the Rocky Mountain System, the Intermontane Plateau, and the Pacific Mountain System are steeper.

The regional curves for the relations between bankfull depth and drainage area for the Laurentian Upland and the Interior Plains are very similar to the nationwide curve, even though the curve for the Interior Plains is flatter than the nationwide curve, indicating that in this region, bankfull depth is larger in small watersheds than on a nationwide average. The regional curves for the Atlantic Plain, Appalachian Highlands, and the Pacific Mountain System are steeper than the nationwide curve and intersect the nationwide curve at drainage areas between about 5 and $30 \mathrm{~km}^{2}$, indicating that bankfull depths for these Physiographic Divisions increase more rapidly with watershed area and are greater than the nationwide average for watersheds larger than a few tens of square kilometers. The curve for the Interior Highlands follows a similar pattern but does not include watersheds smaller than $78 \mathrm{~km}^{2}$ and hence lies

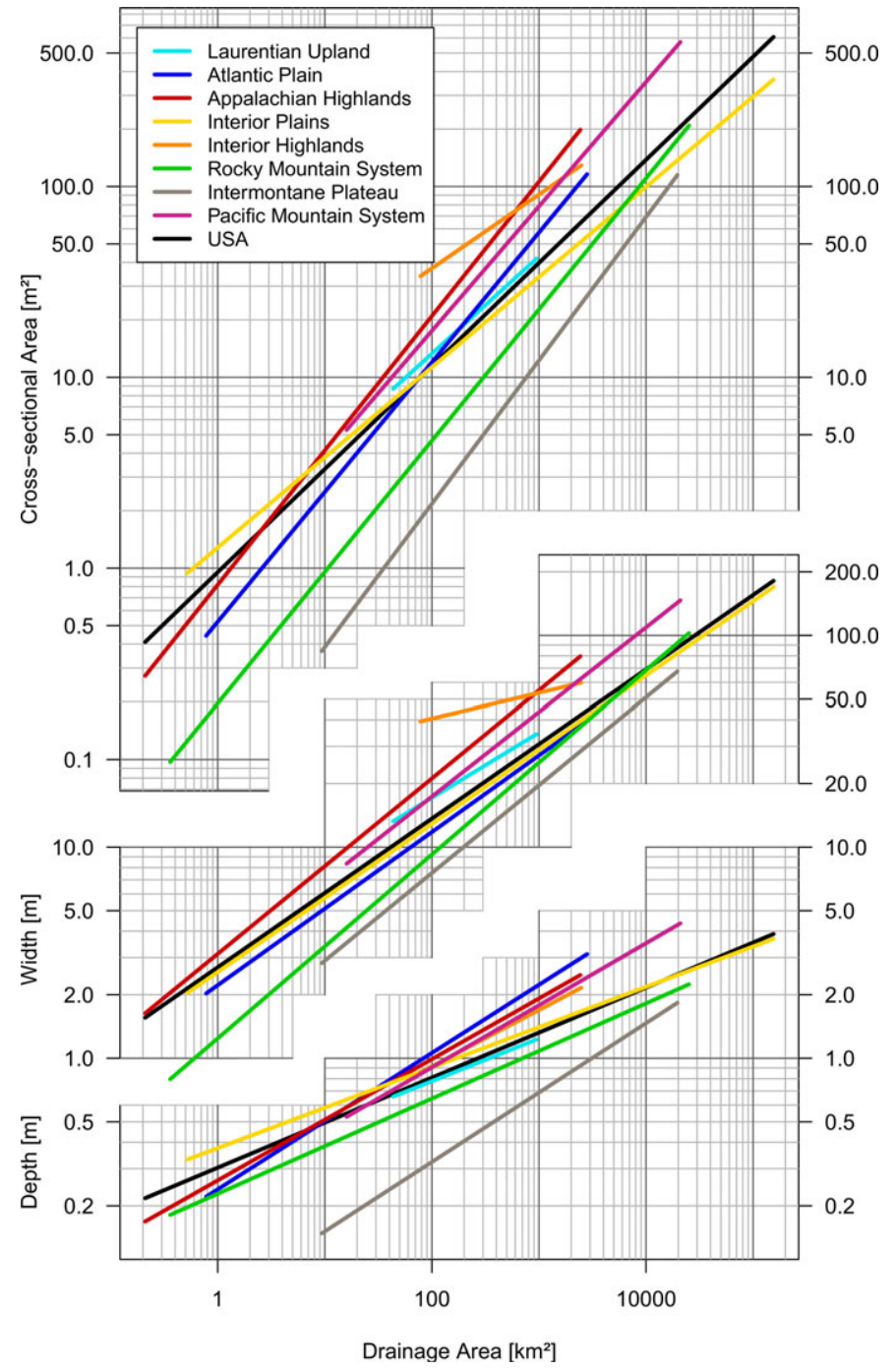

FIGURE 2. Regional and Nationwide Curves Relating Bankfull Width, Depth, and Cross-Sectional Area to Drainage Area.

entirely above the national curve. The curve for the Intermontane Plateau is also considerably steeper than the nationwide curve but plots well below it, indicating that bankfull depth for streams in this Physiographic Division is considerably smaller than the nationwide average for watersheds of similar size, although this difference diminishes for very large watersheds. The curve for the Rocky Mountain System also plots slightly below the nationwide curve but has a similar slope, indicating that bankfull depth for streams in this Physiographic Division tends to be somewhat smaller than the nationwide average.

Visual comparison of the regional curves relating bankfull cross-sectional area to drainage area reveals that the curve for the Laurentian Upland is very similar to the nationwide model, but slightly flatter. The curves for the Interior Highlands and the Interior Plains are also flatter than the nationwide curve and 
the former additionally plots well above it. The curve for the Interior Plains intersects the nationwide curve at drainage areas of about $80 \mathrm{~km}^{2}$. The regional curves for the Atlantic Plain, Appalachian Highlands, Rocky Mountain System, Intermontane Plateau, and the Pacific Mountain System are steeper than the nationwide curve. The curves for the Rocky Mountain System and the Intermontane Plateau plot well below the nationwide curve, while the curve for the Pacific Mountain System plots above it. This indicates that bankfull cross-sectional area for streams in these Physiographic Provinces is generally larger and smaller, respectively, than the nationwide average for streams of comparable drainage area. The curves for the Atlantic Plain and the Appalachian Highlands intersect the nationwide curve at drainage areas of about 80 and $2.5 \mathrm{~km}^{2}$, respectively.

\section{Statistical Evaluation of the Regional and Nationwide Regression Equations}

Analysis of the $\mathrm{HG}$ relationships and regional curves for the conterminous U.S. and for the eight
Physiographic Divisions showed that drainage area is generally a good explanatory variable for bankfull width, depth, and cross-sectional area. Table 3 lists the regression equations for bankfull width, depth, and cross-sectional area as a function of drainage area and the corresponding $R^{2}$ and SEE values.

With regard to bankfull width, the regional models for the Atlantic Plain, the Appalachian Highlands, the Interior Plains, the Rocky Mountain System, and the Pacific Mountain System have higher $R^{2}$ values than the pooled nationwide model, while the $R^{2}$ values for the Laurentian Upland, the Interior Highlands, and the Intermontane Plateau are lower. The regional models predicting bankfull depth as a function of drainage area have higher $R^{2}$ values than the nationwide model in all Physiographic Divisions except for the Laurentian Upland and the Interior Plains. Regarding bankfull cross-sectional area, the regional models have higher $R^{2}$ values than the nationwide model in all Physiographic Divisions except the Laurentian Upland and the Interior Highlands (Table 3). These results indicate that in 17 of 24 regional models, the drainage area accounts for more variation in bankfull channel dimensions than

TABLE 3. Regional Regression Equations for Bankfull Width, Depth, and Cross-Sectional Area as a Function of Drainage Area and Corresponding $R^{2}$ and Standard Error of Estimate (SEE) Values ( $\mathrm{SEE}_{\mathrm{NAT}}=\mathrm{SEE}$ for the national model applied to the subset of sites within each region, $\mathrm{SEE}_{\mathrm{PD}}=\mathrm{SEE}$ for the regional model, Physiographic Division abbreviations as in Table 2).

\begin{tabular}{|c|c|c|c|c|c|c|}
\hline & $\begin{array}{c}\text { Physiographic } \\
\text { Division }\end{array}$ & No. of Sites & $\begin{array}{c}\text { Regression } \\
\text { Equation }\end{array}$ & $R^{2}$ & SEE $_{\text {NAT }}$ & $\mathbf{S E E}_{\mathbf{P D}}$ \\
\hline \multirow[t]{9}{*}{ Bankfull width } & LUP & 6 & $4.15 \mathrm{DA}^{0.308}$ & 0.54 & 0.18 & 0.15 \\
\hline & APL & 61 & $2.22 \mathrm{DA}^{0.363}$ & 0.84 & 0.14 & 0.13 \\
\hline & AHI & 377 & $3.12 \mathrm{DA}^{0.415}$ & 0.87 & 0.22 & 0.12 \\
\hline & IPL & 414 & $2.56 \mathrm{DA}^{0.351}$ & 0.75 & 0.22 & 0.22 \\
\hline & IHI & 7 & $23.23 \mathrm{DA}^{0.121}$ & 0.27 & 0.41 & 0.12 \\
\hline & RMS & 278 & $1.24 \mathrm{DA}^{0.435}$ & 0.76 & 0.26 & 0.20 \\
\hline & IMP & 88 & $1.11 \mathrm{DA}^{0.415}$ & 0.62 & 0.36 & 0.29 \\
\hline & PMS & 48 & $2.76 \mathrm{DA}^{0.399}$ & 0.74 & 0.22 & 0.15 \\
\hline & USA & 1,279 & $2.70 \mathrm{DA}^{0.352}$ & 0.66 & 0.24 & - \\
\hline \multirow[t]{9}{*}{ Bankfull depth } & LUP & 6 & $0.31 \mathrm{DA}^{0.202}$ & 0.37 & 0.14 & 0.14 \\
\hline & APL & 61 & $0.24 \mathrm{DA}^{0.323}$ & 0.75 & 0.20 & 0.15 \\
\hline & AHI & 377 & $0.26 \mathrm{DA}^{0.287}$ & 0.77 & 0.15 & 0.12 \\
\hline & IPL & 394 & $0.38 \mathrm{DA}^{0.191}$ & 0.38 & 0.26 & 0.25 \\
\hline & IHI & 7 & $0.27 \mathrm{DA}^{0.267}$ & 0.52 & 0.19 & 0.15 \\
\hline & RMS & 273 & $0.23 \mathrm{DA}^{0.225}$ & 0.49 & 0.21 & 0.19 \\
\hline & IMP & 88 & $0.07 \mathrm{DA}^{0.329}$ & 0.58 & 0.41 & 0.25 \\
\hline & PMS & 48 & $0.23 \mathrm{DA}^{0.294}$ & 0.50 & 0.23 & 0.19 \\
\hline & USA & 1,254 & $0.30 \mathrm{DA}^{0.213}$ & 0.43 & 0.23 & - \\
\hline \multirow{9}{*}{$\begin{array}{l}\text { Bankfull cross-sectional } \\
\text { area }\end{array}$} & LUP & 6 & $1.27 \mathrm{DA}^{0.509}$ & 0.50 & 0.27 & 0.26 \\
\hline & APL & 61 & $0.52 \mathrm{DA}^{0.680}$ & 0.84 & 0.26 & 0.23 \\
\hline & $\mathrm{AHI}$ & 377 & $0.82 \mathrm{DA}^{0.704}$ & 0.90 & 0.31 & 0.18 \\
\hline & IPL & 216 & $1.28 \mathrm{DA}^{0.472}$ & 0.65 & 0.38 & 0.37 \\
\hline & IHI & 7 & $6.28 \mathrm{DA}^{0.387}$ & 0.55 & 0.53 & 0.21 \\
\hline & RMS & 122 & $0.20 \mathrm{DA}^{0.688}$ & 0.74 & 0.50 & 0.32 \\
\hline & IMP & 88 & $0.07 \mathrm{DA}^{0.751}$ & 0.64 & 0.78 & 0.50 \\
\hline & PMS & 48 & $0.87 \mathrm{DA}^{0.652}$ & 0.66 & 0.42 & 0.30 \\
\hline & USA & 925 & $0.95 \mathrm{DA}^{0.540}$ & 0.58 & 0.42 & - \\
\hline
\end{tabular}


in the nationwide model. It is important to note that the Laurentian Upland and the Interior Highlands have sample sizes in the single digits, which is insufficient for the development of meaningful $\mathrm{HG}$ relationships. Results for these two Physiographic Divisions are included in the graphs, tables, and analysis for the sake of completeness, but are tentative at best and should only be interpreted with care.

All SEE values for the regional models are equal to or lower than those for the nationwide equation applied to the subset of sites within the corresponding Physiographic Division, indicating a lower deviation of observed data from the data predicted by the regional models than from data predicted by the nationwide model (Table 3). Accordingly, the regional models can be assumed to be more reliable in predicting bankfull channel dimensions than the nationwide model, even though in some cases, the regional models have lower $R^{2}$ values than the nationwide model. Since our interest is in predicting bankfull channel dimensions based on drainage area, SEE is in this case a more relevant criterion than $R^{2}$.
Table 4 lists the channel dimensions predicted by the regional and nationwide regression equations for watersheds with an area of $1,10,100$, and $1,000 \mathrm{~km}^{2}$ and their relative differences. The percentage differences indicate that the channel dimensions predicted using the regional equations differ considerably from those predicted using the nationwide curve, especially with regard to bankfull width and cross-sectional area. Relative differences are particularly high in the Interior Highlands, which can be attributed to the small number of measurement sites in this region and to extrapolating the regional relationship well beyond the range of the regional data used for model development.

\section{Effects of Finer Stratification}

To test the effects of a finer stratification of the available data, regional models were also developed for the Physiographic Provinces (Table 5). The Laurentian Upland is not subdivided into provinces and the Atlantic Plain is subdivided into the Continental

TABLE 4. Predicted Channel Dimensions Using the Regional and Nationwide Regression Equations for Bankfull Width, Depth, and Cross-Sectional Area and Relative Difference of the Dimensions (in parentheses) Predicted by the Regional Curves from the Nationwide Curve (Physiographic Division abbreviations as in Table 2).

\begin{tabular}{|c|c|c|c|c|c|}
\hline & \multirow{2}{*}{$\begin{array}{c}\text { Physiographic } \\
\text { Division }\end{array}$} & \multicolumn{4}{|c|}{ Predicted Channel Dimensions (m) and Relative Differences (\%) } \\
\hline & & $1 \mathbf{k m}^{2}$ & $10 \mathrm{~km}^{2}$ & $100 \mathrm{~km}^{2}$ & $1,000 \mathrm{~km}^{2}$ \\
\hline Bankfull width & $\begin{array}{l}\text { LUP } \\
\text { APL } \\
\text { AHI } \\
\text { IPL } \\
\text { IHI } \\
\text { RMS } \\
\text { IMP } \\
\text { PMS } \\
\text { USA }\end{array}$ & $\begin{array}{l}4.15(+54)^{*} \\
2.22(-18) \\
3.12(+16) \\
2.56(-5) \\
23.23(+761)^{*} \\
1.24(-54) \\
1.11(-59) \\
2.76(+2) \\
2.70\end{array}$ & $\begin{array}{l}8.43(+39)^{*} \\
5.11(-16) \\
8.13(+34) \\
5.74(-5) \\
30.70(+406)^{*} \\
3.39(-44) \\
2.90(-52) \\
6.92(+14) \\
6.07\end{array}$ & $\begin{array}{l}17.13(+26) \\
11.79(-14) \\
21.15(+55) \\
12.88(-6) \\
40.55(+197) \\
9.23(-32) \\
7.54(-45) \\
17.35(+27) \\
13.65\end{array}$ & $\begin{array}{l}34.82(+13) \\
27.17(-11) \\
55.03(+79) \\
28.89(-6) \\
53.58(+75) \\
25.15(-18) \\
19.62(-36) \\
43.52(+42) \\
30.70\end{array}$ \\
\hline Bankfull depth & $\begin{array}{l}\text { LUP } \\
\text { APL } \\
\text { AHI } \\
\text { IPL } \\
\text { IHI } \\
\text { RMS } \\
\text { IMP } \\
\text { PMS } \\
\text { USA }\end{array}$ & $\begin{array}{l}0.31(+1)^{*} \\
0.24(-21) \\
0.26(-13) \\
0.38(+24) \\
0.27(-12)^{*} \\
0.23(-25) \\
0.07(-77) \\
0.23(-23) \\
0.30\end{array}$ & $\begin{array}{l}0.49(-1)^{*} \\
0.50(+2) \\
0.51(+3) \\
0.58(+18) \\
0.50( \pm 0)^{*} \\
0.38(-23) \\
0.15(-69) \\
0.46(-7) \\
0.50\end{array}$ & $\begin{array}{l}0.78(-4) \\
1.06(+31) \\
0.99(+22) \\
0.90(+12) \\
0.92(+13) \\
0.64(-20) \\
0.32(-60) \\
0.91(+12) \\
0.81\end{array}$ & $\begin{array}{l}1.24(-6) \\
2.23(+68) \\
1.92(+45) \\
1.40(+6) \\
1.69(+28) \\
1.08(-18) \\
0.69(-48) \\
1.78(+35) \\
1.32\end{array}$ \\
\hline $\begin{array}{l}\text { Bankfull cross-sectional } \\
\text { area }\end{array}$ & $\begin{array}{l}\text { LUP } \\
\text { APL } \\
\text { AHI } \\
\text { IPL } \\
\text { IHI } \\
\text { RMS } \\
\text { IMP } \\
\text { PMS } \\
\text { USA }\end{array}$ & $\begin{array}{l}1.27(+34)^{*} \\
0.52(-45) \\
0.82(-14) \\
1.28(+35) \\
6.28(+559) * \\
0.20(-79) \\
0.07(-93) \\
0.87(-9) \\
0.95\end{array}$ & $\begin{array}{c}4.11(+24)^{*} \\
2.51(-24) \\
4.14(+25) \\
3.81(+15) \\
15.29(+363)^{*} \\
0.96(-71) \\
0.39(-88) \\
3.91(+18) \\
3.31\end{array}$ & $\begin{array}{l}13.30(+16) \\
11.99(+5) \\
20.94(+83) \\
11.30(-1) \\
37.25(+225) \\
4.66(-59) \\
2.17(-81) \\
17.52(+53) \\
11.46\end{array}$ & $\begin{array}{c}42.98(+8) \\
57.36(+44) \\
105.88(+166) \\
33.53(-16) \\
90.74(+128) \\
22.68(-43) \\
12.26(-69) \\
78.62(+98) \\
39.77\end{array}$ \\
\hline
\end{tabular}

"Values are extrapolated outside the range of drainage areas in the regional samples. 
Bieger, Rathuens, Allen, and Arnold

TABLE 5. Number of Sites, $R^{2}$, and Standard Error of Estimate (SEE) Values of the Regression Models for the Physiographic Divisions and Provinces (Physiographic Division abbreviations as in Table 2). For the Physiographic Provinces, the SEE for the division-level model applied to the subset of sites within each province and the SEE for the province-level model are listed.

\begin{tabular}{|c|c|c|c|c|c|c|c|c|c|}
\hline \multirow{2}{*}{$\begin{array}{l}\text { Physiographic Division/ } \\
\text { Province }\end{array}$} & \multicolumn{3}{|c|}{ Bankfull Width } & \multicolumn{3}{|c|}{ Bankfull Depth } & \multicolumn{3}{|c|}{ Bankfull Cross-Sectional Area } \\
\hline & No. of Sites & $R^{2}$ & SEE & No. of Sites & $R^{2}$ & SEE & No. of Sites & $R^{2}$ & SEE \\
\hline AHI & 377 & 0.87 & 0.12 & 377 & 0.77 & 0.12 & 377 & 0.90 & 0.18 \\
\hline Adirondack & 7 & 0.96 & $0.13 / 0.09$ & 7 & 0.91 & $0.13 / 0.10$ & 7 & 0.99 & $0.19 / 0.09$ \\
\hline Appalachian Plateaus & 178 & 0.88 & $0.13 / 0.13$ & 178 & 0.77 & $0.13 / 0.13$ & 178 & 0.91 & $0.19 / 0.19$ \\
\hline Blue Ridge & 11 & 0.73 & $0.11 / 0.11$ & 11 & 0.70 & $0.10 / 0.09$ & 11 & 0.83 & $0.16 / 0.14$ \\
\hline New England & 27 & 0.59 & $0.14 / 0.12$ & 27 & 0.60 & $0.10 / 0.10$ & 27 & 0.75 & $0.19 / 0.15$ \\
\hline Piedmont & 71 & 0.90 & $0.12 / 0.10$ & 71 & 0.77 & $0.14 / 0.13$ & 71 & 0.93 & $0.15 / 0.15$ \\
\hline St. Lawrence Valley & 5 & 0.42 & $0.09 / 0.07$ & 5 & 0.05 & $0.14 / 0.09$ & 5 & 0.76 & $0.13 / 0.05$ \\
\hline Valley and Ridge & 78 & 0.87 & $0.12 / 0.11$ & 78 & 0.84 & $0.10 / 0.09$ & 78 & 0.87 & $0.21 / 0.19$ \\
\hline IPL & 414 & 0.75 & 0.22 & 394 & 0.38 & 0.25 & 216 & 0.65 & 0.37 \\
\hline Central Lowland & 254 & 0.79 & $0.18 / 0.18$ & 250 & 0.34 & $0.23 / 0.23$ & 139 & 0.66 & $0.35 / 0.35$ \\
\hline Great Plains & 83 & 0.83 & $0.32 / 0.22$ & 76 & 0.25 & $0.34 / 0.29$ & 9 & 0.09 & $0.70 / 0.48$ \\
\hline Interior Low Plateaus & 77 & 0.81 & $0.20 / 0.15$ & 68 & 0.86 & $0.22 / 0.13$ & 68 & 0.91 & $0.37 / 0.21$ \\
\hline IHI & 7 & 0.27 & 0.12 & 7 & 0.52 & 0.15 & 7 & 0.55 & 0.21 \\
\hline Ouachita & 2 & - & - & 2 & - & - & 2 & - & - \\
\hline Ozark Plateaus & 5 & 0.76 & $0.07 / 0.05$ & 5 & 0.86 & $0.17 / 0.10$ & 5 & 0.89 & $0.22 / 0.13$ \\
\hline RMS & 278 & 0.76 & 0.20 & 273 & 0.49 & 0.19 & 122 & 0.74 & 0.32 \\
\hline Middle Rocky M. & 15 & 0.79 & $0.19 / 0.17$ & 13 & 0.16 & $0.31 / 0.30$ & 0 & - & - \\
\hline Northern Rocky M. & 209 & 0.76 & $0.21 / 0.21$ & 206 & 0.55 & $0.19 / 0.18$ & 98 & 0.78 & $0.32 / 0.32$ \\
\hline Southern Rocky M. & 38 & 0.71 & $0.18 / 0.16$ & 38 & 0.70 & $0.18 / 0.10$ & 22 & 0.72 & $0.31 / 0.23$ \\
\hline Wyoming Basin & 16 & 0.63 & $0.25 / 0.24$ & 16 & 0.47 & $0.24 / 0.20$ & 2 & - & - \\
\hline IMP & 88 & 0.62 & 0.29 & 88 & 0.58 & 0.25 & 88 & 0.64 & 0.50 \\
\hline Basin and Range & 41 & 0.63 & $0.26 / 0.18$ & 41 & 0.55 & $0.20 / 0.15$ & 41 & 0.65 & $0.44 / 0.32$ \\
\hline Colorado Plateaus & 28 & 0.48 & $0.39 / 0.27$ & 28 & 0.56 & $0.33 / 0.27$ & 28 & 0.68 & $0.56 / 0.39$ \\
\hline Columbia Plateau & 19 & 0.88 & $0.17 / 0.14$ & 19 & 0.52 & $0.20 / 0.14$ & 19 & 0.51 & $0.57 / 0.55$ \\
\hline PMS & 48 & 0.74 & 0.15 & 48 & 0.50 & 0.19 & 48 & 0.66 & 0.30 \\
\hline Cascade-Sierra M. & 19 & 0.60 & $0.17 / 0.16$ & 19 & 0.56 & $0.18 / 0.15$ & 19 & 0.66 & $0.29 / 0.27$ \\
\hline Lower Californian & 0 & - & - & 0 & - & - & 0 & - & - \\
\hline Pacific Border & 29 & 0.80 & $0.15 / 0.15$ & 29 & 0.56 & $0.20 / 0.19$ & 29 & 0.71 & $0.31 / 0.30$ \\
\hline
\end{tabular}

Shelf and the Coastal Plain, but there is no data available for the former. Accordingly, analysis of the effects of finer stratification was not possible in these two Physiographic Divisions. Also, there were no data available for the Lower Californian Province in the Pacific Mountain System. The small number of sites in the Adirondack and St. Lawrence Valley Provinces in the Appalachian Highlands and the Ouachita and the Ozark Plateaus Provinces in the Interior Highlands prevented the development of statistically meaningful HG relationships. Therefore, these provinces were excluded from the statistical analysis of the effects of finer stratification, even though for the sake of completeness $R^{2}$ and SEE values are included in Table 5. This left a total of 17 Physiographic Provinces for statistical analysis of bankfull width and depth, 5 in the Appalachian Highlands, 3 in the Interior Plains, 4 in the Rocky Mountain System, 3 in the Intermontane Plateau, and 2 in the Pacific Mountain System (Table 5). With regard to bankfull cross-sectional area, the lack of sites with observed data in the Middle Rocky Mountains and the Wyoming Basin in the Rocky Mountain System made analysis in these two provinces impossible.

The SEE values indicate that the development of bankfull HG models for smaller regions generally improves the regression equations, even though the $R^{2}$ values are not higher in all cases (Table 5). The $R^{2}$ values for the province-level models are higher than, equal to, and lower than the $R^{2}$ values for the division-level models in 23,5 , and 21 of 49 models across the three variables, respectively, which corresponds to 47,10 , and $43 \%$, respectively. This indicates that in only about half of the province-level models the drainage area accounts for more variation in bankfull channel dimensions than in the division-level models. The SEE values for the province-level models are equal to the SEE values for the division-level models in 12 of 49 models (24\%) across the three variables and lower in 37 of 49 models (76\%) across the three variables. This suggests that the province-level models generally provide more reliable predictions than the divisionlevel models. However, it is important to note that in some provinces the data for all sites used in this study 
may come from a single publication and thus possibly from one individual stream or a few streams that are located very close together. Accordingly, the regression equation may not necessarily be representative for the entire Physiographic Province.

\section{Performance of Drainage Area as a Surrogate for Bankfull Discharge}

Bankfull discharge is generally considered to be a more reliable predictor of bankfull HG than drainage area, because it takes a number of watershed characteristics into account that affect runoff processes and hence the magnitude and duration of bankfull discharge. However, the use of drainage area as a surrogate for bankfull discharge allows for the use of regression equations in ungauged watersheds, which is critical for most of the stream restoration projects. In this study, it was found that bankfull discharge generally explained more variation in bankfull width, depth, and cross-sectional area than did drainage area (Table 6), except for bankfull width in the Appalachian Highlands and in the Pacific Mountain System. For the conterminous U.S., $R^{2}$ values for the models predicting bankfull width, depth, and crosssectional area as a function of drainage area are 0.66 , 0.43 , and 0.58 , respectively, whereas $R^{2}$ values for the models predicting bankfull width, depth, and crosssectional area as a function of bankfull discharge are $0.84,0.73$, and 0.89 , respectively. However, according to the SEE values, drainage area is a more reliable predictor of bankfull width than bankfull discharge in the Atlantic Plain, the Interior Plains, and the Rocky Mountain System. In the Interior Highlands, the model predicting bankfull depth as a function of drainage area has a lower SEE value than the model predicting bankfull depth as a function of bankfull discharge. According to the SEE values, drainage area is a better predictor of bankfull cross-sectional area than bankfull discharge in the Atlantic Plain.

\section{DISCUSSION}

Bankfull HG relationships and regional curves are useful tools for identifying bankfull channel dimensions. However, as Table 4 shows, predicted channel dimensions can vary considerably depending on the regression equation used. Therefore, it is very important to carefully analyze the uncertainty associated with the regression equations, which can be introduced by different sources of error.

The reliability of the regional regression equations is highly dependent on the correct identification of bankfull stage in the field. Williams (1978) lists more than 10 different indicators for identifying bankfull stage, including the floodplain break in slope, back of point bars, most prominent bench, top of bank, highest scour line, change in bank materials, and change in vegetation (Leopold, 1994). Johnson and Heil (1996) found considerable variability in bankfull channel dimensions and bankfull discharge when applying a range of these methods of determining bankfull stage to a river in Maryland. Ideally, a variety of indicators is used in the field (Sherwood and Huitger, 2005). Johnson and Heil (1996) suggested the use of fuzzy numbers to describe bankfull dimensions rather than a deterministic value. As the database used in this study combines data from a number of publications (Table 1), there is considerable uncertainty inherent in the regression equations because of the different indicators used for identifying bankfull stage in different studies.

Naturally occurring heterogeneity in a population is called variability (Harman et al., 2008). Models

TABLE 6. Comparison of $R^{2}$ and Standard Error of Estimate (SEE) Values of the Regression Models Relating Bankfull Width, Depth, and Cross-Sectional Area to Drainage Area and Bankfull Discharge (Physiographic Division abbreviations as in Table 2).

\begin{tabular}{|c|c|c|c|c|c|c|}
\hline \multirow[b]{2}{*}{$\begin{array}{l}\text { Physiographic } \\
\text { Division }\end{array}$} & \multicolumn{2}{|c|}{ Bankfull Width } & \multicolumn{2}{|c|}{ Bankfull Depth } & \multicolumn{2}{|c|}{$\begin{array}{c}\text { Bankfull Cross-Sectional } \\
\text { Area }\end{array}$} \\
\hline & $\begin{array}{l}\boldsymbol{R}^{2} / \mathbf{S E E} \\
\quad(\mathrm{DA})\end{array}$ & $\begin{array}{l}\boldsymbol{R}^{2} / \mathbf{S E E} \\
\quad(\boldsymbol{Q})\end{array}$ & $\begin{array}{l}\boldsymbol{R}^{2} / \mathbf{S E E} \\
\quad(\mathrm{DA})\end{array}$ & $\begin{array}{l}\boldsymbol{R}^{2} / \mathbf{S E E} \\
\quad(\boldsymbol{Q})\end{array}$ & $\begin{array}{l}\boldsymbol{R}^{2} / \mathbf{S E E} \\
\quad(\mathbf{D A})\end{array}$ & $\begin{array}{l}R^{2} / \text { SEE } \\
\quad(Q)\end{array}$ \\
\hline LUP & $0.54 / 0.15$ & $0.80 / 0.10$ & $0.37 / 0.14$ & $0.64 / 0.10$ & $0.50 / 0.26$ & $0.80 / 0.17$ \\
\hline APL & $0.84 / 0.13$ & $0.74 / 0.16$ & $0.75 / 0.15$ & $0.83 / 0.12$ & $0.84 / 0.23$ & $0.84 / 0.24$ \\
\hline AHI & $0.87 / 0.12$ & $0.88 / 0.11$ & $0.77 / 0.12$ & $0.81 / 0.11$ & $0.90 / 0.18$ & $0.93 / 0.15$ \\
\hline IPL & $0.75 / 0.22$ & $0.78 / 0.18$ & $0.38 / 0.25$ & $0.63 / 0.17$ & $0.65 / 0.37$ & $0.87 / 0.22$ \\
\hline IHI & $0.27 / 0.12$ & $0.91 / 0.03$ & $0.52 / 0.15$ & $0.56 / 0.19$ & $0.55 / 0.21$ & $0.68 / 0.21$ \\
\hline RMS & $0.76 / 0.20$ & $0.82 / 0.17$ & $0.49 / 0.19$ & $0.81 / 0.11$ & $0.74 / 0.32$ & $0.92 / 0.18$ \\
\hline IMP & $0.62 / 0.29$ & $0.91 / 0.15$ & $0.58 / 0.25$ & $0.87 / 0.14$ & $0.64 / 0.50$ & $0.90 / 0.28$ \\
\hline PMS & $0.74 / 0.15$ & $0.71 / 0.16$ & $0.50 / 0.19$ & $0.74 / 0.13$ & $0.66 / 0.30$ & $0.83 / 0.21$ \\
\hline USA & $0.66 / 0.24$ & $0.84 / 0.16$ & $0.43 / 0.23$ & $0.73 / 0.15$ & $0.58 / 0.42$ & $0.89 / 0.22$ \\
\hline
\end{tabular}


have to be able to account for this variability to reduce uncertainty associated with model predictions. For this, it is critical to have sufficient knowledge about the factors causing natural variability and to make sure that the sample represents the population as well as possible. The representative status of a sample depends on the sample size and the population it is supposed to represent. If any statistical significance is to be attributed to the results of bankfull HG regression equations, a suitably large sample size is very important (Park, 1977). However, in many studies, the sample size is limited by the availability of stream reaches that are suitable for conducting bankfull HG measurements. In this study, a limited number of sites with measurement data are available for some of the Physiographic Divisions, especially for the small ones (Laurentian Upland and Interior Highlands) (Figure 1 and Table 2). In large, topographically and climatically diverse divisions even a large number of sites may not be sufficient if the natural variability is too high to be accounted for by a single equation, especially when the sample locations are clustered and likely not representative of the region as a whole (e.g., in the Interior Plains and the Intermontane Plateau). The regression equations developed in this study should be applied with caution to streams in areas, from which no sites were used for model development, e.g., the Mississippi Alluvial Plain and the West Gulf Coastal Plain in the Atlantic Plain, the Great Basin Section in the Intermontane Plateau, or the Sierra Nevada in the Pacific Mountain System.

Also, measurements often do not cover a sufficiently wide range of watershed areas to make reliable predictions especially for very small watersheds (Table 2). According to Mulvihill et al. (2009), this is a concern because small channels are characterized by particularly variable bankfull hydraulic dimensions. In this study, data on very small watersheds are available for some, but not all of the Physiographic Divisions. Predictions of channel dimensions from the regional curves should be limited to drainage basin sizes that were accounted for in the dataset used for model development, or at least results extrapolated beyond this range should be treated with caution (see predicted values for small watersheds in the Laurentian Upland and the Interior Highlands in Table 4).

Bankfull regional curves are a simplification of complex natural processes, which are influenced by a large number of factors including precipitation, soils, and vegetation (McCandless and Everett, 2002). Identifying the causes of natural variability can help to integrate additional independent variables in a model to explain a higher degree of variability in the dependent variable. When bankfull channel dimensions are predicted only by drainage area, all other possibly influencing factors are assumed to vary consistently within the region of interest. Accordingly, it is widely recognized that bankfull $\mathrm{HG}$ relationships are only valid within relatively homogenous regions (McCandless and Everett, 2002). Discharge is assumed to scale systematically with drainage area (Ames et al., 2009). However, as discharge is directly influenced by spatial variations in climate, topography, soils, land cover, and in-stream factors, drainage area is not necessarily a suitable surrogate for discharge. Results of this study show that drainage area performs reasonably well in predicting channel dimensions (Table 3). However, when using bankfull discharge as the independent variable, most of the regional curves for all three dependent variables (bankfull width, depth, and cross-sectional area) have higher $R^{2}$ and lower SEE values compared to the regional curves that are based on drainage area (Table 6), since discharge accounts for variability caused by factors other than drainage area. He and Wilkerson (2011) found that in some cases using the two-year return-period discharge $\left(Q_{2}\right)$ instead of drainage area to predict bankfull width, depth, and cross-sectional area results in more reliable models, which they attribute to the fact that $Q_{2}$ estimates (like bankfull discharge, which $Q_{2}$ approximates) integrate not only the drainage area but also climate and geology. According to Wilkerson (2008), estimates of $Q_{2}$ are available for large parts of the U.S.

Many authors have tried to reduce the variability of a population by regionalizing the available data according to a number of criteria to minimize the variability of influencing factors. Data have been stratified by ecoregions (Castro and Jackson, 2001; Faustini et al., 2009; Splinter et al., 2010), hydrologic regions (Mulvihill and Baldigo, 2012), water resources regions (Faustini et al., 2009), and physiographic regions (Castro and Jackson, 2001; Johnson and Fecko, 2008). However, only Faustini et al. (2009) evaluated the effects of regionalization for the entire conterminous U.S. They found that both approaches to regionalization they evaluated (ecoregions and water resources regions) performed equally well in developing reliable regression equations relating bankfull width to drainage area. In this study, it was shown that regionalization based on Physiographic Divisions also results in reliable bankfull HG relationships, not only for bankfull width but also for bankfull depth and cross-sectional area, and improves the regression equations as compared to a nationwide model (Table 3).

Some authors have tried stratifying data according to mean annual precipitation, mean annual runoff, channel slope, or stream type (Rosgen, 1996; Miller and Davis, 2003; Lawlor, 2004; Powell et al., 2004; Mulvihill et al., 2009). The USDA-NRCS (2007) 
suggests constructing separate regional curves for forested/rangeland, agricultural, and urban areas. Others have used these additional influencing factors for multiple linear regression analysis to better explain the natural variability of a population that is not explained by drainage area and thereby improve regional predictive relationships for bankfull channel dimensions (e.g., Elliott and Cartier, 1986; Hey and Thorne, 1986; Julien and Wargadalam, 1995; Lee and Julien, 2006; Faustini et al., 2009). Some of these authors included variables like the median grain size of the bed material $\left(D_{50}\right)$, the density of bank vegetation, the channel slope, or the Shields parameter in their regression equations. Even though these variables have shown to impact channel dimensions (Leopold et al., 1964; Allen et al., 1994; Hession et al., 2003; Anderson et al., 2004), observed data required to develop reliable equations over large geographic areas is not available. For modeling purposes, a comprehensive set of regression equations to predict channel dimensions based on readily available data is of greater significance than more advanced equations accounting for local variability. Wilkerson et al. (2014) showed that precipitation is a factor influencing the relationship between bankfull width and drainage area. Precipitation is one of the basic model inputs for hydrologic models like SWAT, so it should generally be available even for poorly gauged watersheds. Therefore, it is a variable that could be used for improving the prediction of bankfull channel dimensions for hydrologic models without limiting the applicability of the equations to well-gauged watersheds.

Faustini et al. (2009) used a large national dataset on HG in wadeable streams to examine the impact of different regionalization schemes and to analyze the potential of incorporating additional independent variables using multiple regression analysis. They concluded from their study that a finer stratification into smaller, more homogenous regions has a higher potential of improving regional predictive relationships than the incorporation of additional independent variables. In contrast, Ames et al. (2009) concluded from their study that both regionalization and the integration of additional watershed variables can improve regression equations predicting stream width and depth. Anderson et al. (2004) and Mulvihill and Baldigo (2012) argue that even highly regionalized curves are often subject to substantial variability and error. Also, finer stratification leads to a smaller number of representative data points per region, which results in less robust equations (Johnson and Fecko, 2008). However, it should be considered an option when there are a sufficient number of sites within a province to develop a reasonably robust $\mathrm{HG}$ equation and when $R^{2}$ and SEE values are considerably higher and lower, respectively. In this study, finer stratification of data and the development of regional curves for Physiographic Provinces instead of Physiographic Divisions resulted in an improvement of $R^{2}$ and SEE values in more than half of the provinces when compared to the corresponding divisions (Table 5). The integration of additional variables in multiple regression analysis has not been tested yet, but may further improve the reliability of bankfull HG relationships. An additional approach suggested by Wilkerson et al. (2014) is developing a linear-piecewise model to predict bankfull width based on drainage area. Using a similar dataset as the one used in this study and the wadeable streams data also used by Faustini et al. (2009), they found out that a two-segment linear-piecewise model provides more reliable predictions of bankfull width than a simple linear model, since it accounts for differences between small and large watersheds (Wilkerson et al., 2014).

\section{SUMMARY AND CONCLUSION}

This study presents a large database integrating bankfull HG data from almost 50 publications. In total, observed data are available for more than 1,300 sites across the conterminous U.S. The data were stratified based on the Physiographic Divisions of the U.S. and bankfull HG regression equations were developed for each of the eight divisions and for the entire conterminous U.S. The equations relate the independent variable drainage area to the dependent variables bankfull width, depth, and cross-sectional area. The reliability of the regional curves was evaluated using the coefficient of determination $\left(R^{2}\right)$ and the SEE. In addition, the effect of finer stratification of data on the basis of Physiographic Provinces and the performance of drainage area as a surrogate for bankfull discharge were assessed.

In conclusion, results indicate the following:

1. In most cases, regional curves for each of the Physiographic Divisions have higher $R^{2}$ values and lower SEE values and thus perform better than the nationwide curve, which confirms the central hypothesis of this study.

2. A finer stratification of data based on Physiographic Provinces improves the reliability of the regression equations in approximately threequarters of the provinces as compared to the corresponding divisions.

3. Despite the large amount of data available in the literature, there are large geographic areas within most of the Physiographic Divisions that are not represented within the dataset used in 
this study, which demands careful consideration of the geographic applicability of the regression equations and points to the need for additional studies to fill the data gaps.

4. Bankfull discharge accounts for a considerably higher degree of variability in bankfull width, depth, and cross-sectional area than does drainage area, which indicates a need for further improvement of the regression equations.

Various authors have improved regional regression equations by either identifying the most suitable means of regionalization or by using multiple linear regression analysis to integrate additional independent variables in the equations. While the first approach focuses on minimizing the variability within the population to improve the representative status of the sample, the second approach aims at identifying and integrating variables that explain variability in the sample that is not explained by drainage area. There is no consensus among researchers with regard to the question, which approach is more appropriate to improve the reliability of bankfull $\mathrm{HG}$ relationships. Either way, when a consistent set of bankfull HG relationships across the conterminous U.S. is supposed to be used in hydrologic models, it is not necessarily expedient to use the variables that are best suited to predicting channel dimensions, but rather to use data that is commonly available or can be derived from GIS data layers with national coverage. In the future, the results of this study will be used as a basis for improving the regional curves by integrating additional readily available variables in the regression equations.

\section{SUPPORTING INFORMATION}

Additional Supporting Information may be found in the online version of this article:

A table listing the regression equations and standard errors of intercept and slope for all Physiographic Divisions and Provinces and seven figures, showing the residuals (predicted-observed bankfull channel dimensions) and their frequency distribution for the Physiographic Divisions and Provinces.

\section{LITERATURE CITED}

Allen, P.M., J.G. Arnold, and B.W. Byars, 1994. Downstream Channel Geometry for Use in Planning-Level Models. Journal of the American Water Resources Association 30(4):663-671, doi: 10.1111/j.1752-1688.1994.tb03321.x.
Ames, D.P., E.B. Rafn, R. Van Kirk, and B. Crosby, 2009. Estimation of Stream Channel Geometry in Idaho Using GIS-Derived Watershed Characteristics. Environmental Modelling and Software 24(3):444-448.

Anderson, R.J., B.P. Bledsoe, and W.C. Hession, 2004. Width of Streams and Rivers in Response to Vegetation, Bank Material, and Other Factors. Journal of the American Water Resources Association 40(5):1159-1172, doi: 10.1111/j.1752-1688.2004. tb01576.x.

Andrews, E.D., 1984. Bed-Material Entrainment and Hydraulic Geometry of Gravel-Bed Rivers in Colorado. Geological Society of America Bulletin 95(3):371-378, doi: 10.1130/0016-7606(1984) 95<371:BEAHGO $>2.0 . \mathrm{CO} ; 2$.

Arnold, J.G., R. Srinivasan, R.S. Muttiah, and J.R. Williams, 1998. Large Area Hydrologic Modeling and Assessment Part I: Model Development. Journal of the American Water Resources Association 34(1):73-89, doi: 10.1111/j.1752-1688.1998.tb05961.x.

Babbit, G.S., 2005. Bankfull Hydraulic Geometry of Streams Draining the Southwestern Appalachians of Tennessee. Master's Thesis, The University of Tennessee, Knoxville, Tennessee.

Bicknell, B.R., J.C. Imhoff, J.L. Kittle, Jr., A.S. Donigian, Jr., and R.C. Johanson, 1997. Hydrological Simulation Program-Fortran, User's Manual for Version 11. U.S. Environmental Protection Agency Report EPA/600/R-97/080, 755 pp.

Brockman, R.R., 2010. Hydraulic Geometry Relationships and Regional Curves for the Inner and Outer Bluegrass Regions of Kentucky. Master's Thesis, University of Kentucky, Lexington, Kentucky.

Castro, J.M. and P.L. Jackson, 2001. Bankfull Discharge Recurrence Intervals and Regional Hydraulic Geometry Relationships: Patterns in the Pacific Northwest, USA. Journal of the American Water Resources Association 37(5):1249-1262, doi: 10.1111/ j.1752-1688.2001.tb03636.x.

Chaplin, J.J., 2005. Development of Regional Curves Relating Bankfull-Channel Geometry and Discharge to Drainage Area for Streams in Pennsylvania and Selected Areas of Maryland. U.S. Geological Survey Scientific Investigations Report 2005-5147, 34 pp. http://pubs.usgs.gov/sir/2005/5147/SIR2005-5147.pdf \.

Cinotto, P.J., 2003. Development of Regional Curves of BankfullChannel Geometry and Discharge for Streams in the NonUrban, Piedmont Physiographic Province, Pennsylvania and Maryland. U.S. Geological Survey Water-Resources Investigations Report 03-4014, 27 pp. https://prod.nrcs.usda.gov/Internet/ FSE_DOCUMENTS/nrcs143_014840.pdf \.

Copeland, R.R., D.S. Biedenharn, and J.C. Fischenich, 2000. Channel-Forming Discharge. U.S. Army Corps of Engineers Technical Note ERDC/CHL CHETN-VIII-5, 10 pp. http://chl.erdc.usace. army.mil/library/publications/chetn/pdf/chetn-viii-5.pdf \.

Dingman, S.L., 2007. Analytical Derivation of At-a-Station Hydraulic-Geometry Relations. Journal of Hydrology 334:17-27, doi: 10.1016/j.jhydrol.2006.09.021.

Doll, B.A., A.D. Dobbins, J. Spooner, D.R. Clinton, and D.A. Bidelspach, 2003. Hydraulic Geometry Relationships for Rural North Carolina Coastal Plain Streams. NC Stream Restoration Institute Report to N.C. Division of Water Quality. https://www. bae.ncsu.edu/programs/extension/wqg/srp/append_a.pdf, accessed August 2013.

Dudley, R.W., 2004. Hydraulic-Geometry Relations for Rivers in Coastal and Central Maine. U.S. Geological Survey Scientific Investigations Report 2004-5042, 30 pp. http://pubs.usgs.gov/sir/ 2004/5042/pdf/sir2004-5042.pdf $\backslash$.

Dunne, T. and L.B. Leopold, 1978. Water in Environmental Planning. Freeman, San Francisco, California, ISBN: 978-0716700791.

Dutnell, R.C., 2000. Development of Bankfull Discharge and Channel Geometry Relationships for Natural Channel Design in Oklahoma Using a Fluvial Geomorphic Approach. Master's Thesis, University of Oklahoma, Norman, Oklahoma. 
Eash, D.A., 1993. Estimating Design-Flood Discharges for Streams in Iowa Using Drainage Basin and Channel-Geometry Characteristics. U.S. Geological Survey Water-Resources Investigations Report 93-4062, 96 pp. http://www.iowadot.gov/operations research/reports/reports_pdf/hr_and_tr/reports/hr322.pdf $\$.

Elliott, J.G. and K.D. Cartier, 1986. Hydraulic Geometry and Streamflow of Channels in the Piceance Basin, Rio Blanco and Garfield Counties, Colorado. U.S. Geological Survey WaterResources Investigations Report 85-4118, 28 pp. http://pubs. usgs.gov/wri/1985/4118/report.pdf $\backslash$.

Emmert, B., 2004. Regional Curve Development for Kansas. In: Proceedings of the ASAE Conference: Self-Sustaining Solutions for Streams, Wetlands, and Watersheds, J. D'Ambrosio (Editor). American Society of Agricultural Engineers, St. Paul, Minnesota, pp. 27-34.

Emmett, W.W., 1975. Hydrologic Evaluation of the Upper Salmon River Area, Idaho. U.S. Geological Survey Professional Paper 870-A, 116 pp. http://pubs.usgs.gov/pp/0870a/report.pdf \.

Faustini, J.M., P.R. Kaufmann, and A.T. Herlihy, 2009. Downstream Variation in Bankfull Width of Wadeable Streams across the Conterminous United States. Geomorphology 108(3-4):292311, doi: 10.1016/j.geomorph.2009.02.005.

Fenneman, N.M. and D.W. Johnson, 1946. Physiographic Divisions of the Conterminous US. U.S. Geological Survey Special Map Series, Scale 1:7,000,000. http://water.usgs.gov/GIS/metadata/ usgswrd/XML/physio.xml, accessed May 2014.

Harman, C., M. Stewardson, and R. DeRose, 2008. Variability and Uncertainty in Reach Bankfull Hydraulic Geometry. Journal of Hydrology 351(1-2):13-25, doi: 10.1016/j.jhydrol.2007.11.015.

Harman, W.H., G.D. Jennings, J. Patterson, D.R. Clinton, L.O. Slate, A.G. Jessup, J.R. Everhart, and R.E. Smith, 1999. Bankfull Hydraulic Geometry Relationships for North Carolina Streams. In: AWRA Wildland Hydrology Symposium Proceedings, D.S. Olson and J.P. Potyondy (Editors). AWRA Summer Symposium, June 30-July 2, 1999, Bozeman, Montana, pp. 401-408.

Harman, W.H., D.E. Wise, M.A. Walker, R. Morris, M.A. Cantrell, M. Clemmons, G.D. Jennings, D.R. Clinton, and J. Patterson, 2000. Bankfull Regional Curves for North Carolina Mountain Streams. In: Proceedings of the AWRA Conference Water Resources in Extreme Environments, May 1-3, 2000, D.L. Kans (Editor). Anchorage, Alaska, pp. 185-190.

Haucke, J. and K.A. Clancy, 2011. Stationarity of Streamflow Records and Their Influence on Bankfull Regional Curves. Journal of the American Water Resources Association 47(6):13381347, doi: 10.1111/j.1752-1688.2011.00590.x.

He, L. and G.V. Wilkerson, 2011. Improved Bankfull Channel Geometry Prediction Using Two-Year Return-Period Discharge. Journal of the American Water Resources Association 47(6): 1298-1316, doi: 10.1111/j.1752-1688.2011.00567.x.

Hession, W.C., J.E. Pizzuto, T.E. Johnson, and R.J. Horwitz, 2003. Influence of Bank Vegetation on Channel Morphology in Rural and Urban Watersheds. Geology 31(1):147-150.

Hey, R.D. and C.R. Thorne, 1986. Stable Channels with Mobile Gravel Beds. Journal of Hydraulic Engineering 112(6):671-689, doi: 10.1061/(ASCE)0733-9429(1986)112:8(671).

Howell, S., 2009. Development of Regional Hydraulic Geometry Curves for the Santa Cruz Mountains. Bachelor's Thesis, California Polytechnic State University, San Luis Obispo, California.

Jaquith, S. and M. Kline, 2006. Vermont Regional Hydraulic Geometry Curves. Vermont Department of Environmental Conservation River Management Program Technical Report, 11 pp. http://www.vtwaterquality.org/rivers/docs/rv_hydraulic geocurves.pdf $\backslash$.

Johnson, B.H. and G. Padmanabhan, 2010. Regression Estimates of Design Flows for Ungaged Sites Using Bankfull Geometry and Flashiness. Catena 81(2):117-125, doi: 10.1016/j.catena. 2010.02.001.
Johnson, P.A., 2006. Assessing Stream Channel Stability at Bridges in Physiographic Regions. U.S. Department of Transportation Publication No. FHWA-HRT-05-072, 157 pp. http:// www.fhwa.dot.gov/publications/research/infrastructure/hydraulics/ 05072/05072.pdf.

Johnson, P.A. and B.J. Fecko, 2008. Regional Channel Geometry Equations: A Statistical Comparison for Physiographic Provinces in the Eastern US. River Research and Applications 24(6):823-834, doi: 10.1002/rra.1080.

Johnson, P.A. and T.M. Heil, 1996. Uncertainty in Estimating Bankfull Conditions. Journal of the American Water Resources Association 32(6):1283-1291, doi: 10.1111/j.1752-1688.1996.tb03497.x.

Julien, P.Y. and J. Wargadalam, 1995. Alluvial Channel Geometry: Theory and Applications. Journal of Hydraulic Engineering 121(4):312-325, doi: 10.1061/(ASCE)0733-9429(1995)121:4(312).

Keaton, J.N., T. Messinger, and E.J. Doheny, 2005. Development and Analysis of Regional Curves for Streams in the Non-Urban Valley and Ridge Physiographic Province, Maryland, Virginia, and West Virginia. U.S. Geological Survey Scientific Investigations Report 2005-5076, 109 pp. http://pubs.usgs.gov/sir/2005/ 5076/sir05_5076.pdf \.

King, J.G., W.W. Emmett, P.J. Whiting, R.P. Kenworthy, and J.J. Barry, 2004. Sediment Transport Data and Related Information for Selected Coarse-Bed Streams and Rivers in Idaho. U.S. Department of Agriculture, Forest Service, Rocky Mountain Research Station General Technical Report RMRS-GTR-131, 26 pp. http://www.fs.fed.us/rm/pubs/rmrs_gtr131.pdf $\backslash$.

Kolberg, F.J. and A.D. Howard, 1995. Active Channel Geometry and Discharge Relations of U.S. Piedmont and Midwestern Streams: The Variable Exponent Model Revisited. Water Resources Research 31(9):2353-2365, doi: 10.1029/95WR01348.

Krstolic, J.L. and J.J. Chaplin, 2007. Bankfull Regional Curves for Streams in the Non-Urban, Non-Tidal Coastal Plain Physiographic Province, Virginia and Maryland. U.S. Geological Survey Scientific Investigations Report 2007-5162, 48 pp. http:// pubs.usgs.gov/sir/2007/5162/pdf/SIR2007-5162.pdf \.

Lawlor, S.M., 2004. Determination of Channel-Morphology Characteristics, Bankfull Discharge, and Various Design-Peak Discharges in Western Montana. U.S. Geological Survey Scientific Investigations Report 2004-5263, 19 pp. http://pubs.usgs.gov/sir/ 2004/5263/pdf/sir_2004_5263.pdf $\backslash$.

Lee, J.S. and P.Y. Julien, 2006. Downstream Hydraulic Geometry of Alluvial Channels. Journal of Hydraulic Engineering 132(12): 1347-1352, doi: 10.1061/(ASCE)0733-9429(2006)132:12(1347).

Leopold, L.B., 1994. A View of the River. Harvard University Press, Cambridge, Massachusetts, ISBN-13: 978-0674018457.

Leopold, L.B. and T. Maddock, 1953. The Hydraulic Geometry of Stream Channels and Some Physiographic Implications. U.S. Geological Survey Professional Paper 252, 56 pp. http://eps. berkeley.edu/people/lunaleopold/(040)\%20The\%20Hydraulic\%20 Geometry\%20of\%20Stream\%20Channels $\% 20$ and $\% 20$ Some $\% 20$ Physiographic\%20Implications.pdf $\backslash$.

Leopold, L.B. and M.G. Wolman, 1957. River Channel Patterns: Braided, Meandering and Straight, Physiographic and Hydraulic Studies of Rivers. U.S. Geological Survey Professional Paper 282-B, 85 pp. http://pubs.er.usgs.gov/publication/pp282B.

Leopold, L.B., M.G. Wolman, and J.P. Miller, 1964. Fluvial Processes in Geomorphology. Freeman, San Francisco, California, ISBN: 0-486-68588-8.

Lotspeich, R.R., 2009. Regional Curves of Bankfull Channel Geometry for Non-Urban Streams in the Piedmont Physiographic Province, Virginia. U.S. Geological Survey Scientific Investigations Report 2009-5206, 51 pp. http://pubs.usgs.gov/sir/2009/ 5206/pdf/sir2009-5206.pdf \.

Mater, B.D., A.C. Parola, and C. Hansen, 2009. Geomorphic Characteristics of Streams in the Western Kentucky Coal Field Physiographic Region of Kentucky. Project Final Report for 
Kentucky Division of Water NPS 02-05, University of Louisville Stream Institute, Louisville, Kentucky, 28 pp. https://louis ville.edu/speed/civil/si/projects/EKCF_Curves.pdf $\backslash$.

McCandless, T.L., 2003a. Bankfull Discharge and Channel Characteristics in the Coastal Plain Hydrologic Region. U.S. Fish \& Wildlife Service Report CBFO-S03-01, 33 pp. http://www.fws. gov/chesapeakebay/pdf/Plateau.pdf $\backslash$.

McCandless, T.L., 2003b. Bankfull Discharge and Channel Characteristics of Streams in the Allegheny Plateau and the Valley and Ridge Hydrologic Regions. U.S. Fish \& Wildlife Service Report CBFO-S03-02, 29 pp. http://www.fws.gov/Chesapeake bay/pdf/plain.pdf $\backslash$.

McCandless, T.L. and R.A. Everett, 2002. Bankfull Discharge and Channel Characteristics of Streams in the Piedmont Hydrologic Region. U.S. Fish \& Wildlife Service Report CBFO-S02-01, 40 pp. http://www.fws.gov/chesapeakebay/pdf/Section1.pdf $\backslash$.

McManamay, R.A., D.J. Orth, C.A. Dolloff, and E.A. Frimpong, 2011. Regional Frameworks Applied to Hydrology: Can Landscape-Based Frameworks Capture the Hydrologic Variability? River Research and Applications 28(9):1325-1339, doi: 10.1002/ rra.1535.

McPherson, J.B., 2011. Bankfull Geomorphic Relationships and Reference Reach Assessment of the Ridge and Valley Physiographic Province of East Tennessee. Master's Thesis, University of Tennessee, Knoxville, Tennessee.

Messinger, T., 2009. Regional Curves for Bankfull Channel Characteristics in the Appalachian Plateaus, West Virginia. U.S. Geological Survey Scientific Investigations Report 2009-5242, 43 pp. http://pubs.usgs.gov/sir/2009/5242/pdf/sir2009-5242.pdf $\backslash$.

Messinger, T. and J.B. Wiley, 2004. Regional Relations in Bankfull Channel Characteristics Determined from Flow Measurements at Selected Stream-Gaging Stations in West Virginia, 19112002. U.S. Geological Survey Water-Resources Investigations Report 03-4276, 31 pp. http://pubs.usgs.gov/wri/wri034276/pdf/ wri03-4276.pdf \.

Metcalf, C., 2004. Regional Channel Characteristics for Maintaining Natural Fluvial Geomorphology in Florida Streams. U.S. Fish and Wildlife Service Technical Report, 39 pp. http:// www.bae.ncsu.edu/people/faculty/jennings/Stream\%20Wkshp/FL $\% 20$ Metcalf\%20USFWS\%20Regional\%20Curves.pdf $\backslash$.

Miller, S.J. and D. Davis, 2003. Optimizing Catskill Mountain Regional Bankfull Discharge and Hydraulic Geometry Relationships. In: Watershed Management for Water Supply Systems: Proceedings of the American Water Resources Association 2003 International Congress, New York City, New York, June 29July 2, 2003, 10 pp. http://www.catskillstreams.org/pdfs/catskill regionalcurves.pdf.

Mistak, J.L. and D.A. Stille, 2008. Regional Hydraulic Geometry Curve for the Upper Menominee River. Michigan Department of Natural Resources Technical Report 2008-1, 19 pp. http:// www.michigan.gov/documents/dnr/2008-1tr_363056_7.pdf.

Mohamoud, Y.M. and R.S. Parmar, 2006. Estimating Streamflow and Associated Hydraulic Geometry, the Mid-Atlantic Region, USA. Journal of the American Water Resources Association 42(3): 755-768, doi: 10.1111/j.1752-1688.2006.tb04490.x.

Moody, T., M. Wirtanen, and S.N. Yard, 2003. Regional Relationships for Bankfull Stage in Natural Channels of the Arid Southwest. Arid SW Regional Report, 36 pp. http://www.natural channeldesign.com/Reports/Arid\%20SW\%20Report.pdf, accessed August 2013.

Moyer, D.L. and M.R. Bennett, 2007. Development of Relations of Stream Stage to Channel Geometry and Discharge for Stream Segments Simulated with Hydrologic Simulation Program-Fortran (HSPF), Chesapeake Bay Watershed and Adjacent Parts of Virginia, Maryland, and Delaware. U.S. Geological Survey Scientific Investigations Report 2007-5135, 83 pp. http://pubs.usgs. gov/sir/2007/5135/pdf/SIR2007-5135.pdf.
Mulvihill, C.I. and B.P. Baldigo, 2007. Regionalized Equations for Bankfull-Discharge and Channel Characteristics of Streams in New York State - Hydrologic Region 3 East of the Hudson River. U.S. Geological Survey Scientific Investigations Report 2007-5227, 15 pp. http://pubs.usgs.gov/sir/2007/5227/pdf/SIR20075227.pdf $\backslash$.

Mulvihill, C.I. and B.P. Baldigo, 2012. Optimizing Bankfull Discharge and Hydraulic Geometry Relations for Streams in New York State. Journal of the American Water Resources Association 48(3):449-463, doi: 10.1111/j.1752-1688.2011.00623.x.

Mulvihill, C.I., B.P. Baldigo, S.J. Miller, D. DeKoskie, and J. DuBois, 2009. Bankfull Discharge and Channel Characteristics of Streams in New York State. U.S. Geological Survey Scientific Investigations Report 2009-5144, 51 pp. http://pubs.usgs.gov/sir/ 2009/5144/pdf/sir2009-5144_mulvihil_bankfull_2revised508.pdf $\$.

Mulvihill, C.I., A.G. Ernst, and B.P. Baldigo, 2005. Regionalized Equations for Bankfull-Discharge and Channel Characteristics of Streams in New York State: Hydrologic Region 6 in the Southern Tier of New York. U.S. Geological Survey Scientific Investigations Report 2005-5100, 14 pp. http://ny.water.usgs. gov/pubs/wri/sir055100/sir2005-5100.pdf \.

Mulvihill, C.I., A.G. Ernst, and B.P. Baldigo, 2006. Regionalized Equations for Bankfull-Discharge and Channel Characteristics of Streams in New York State: Hydrologic Region 7 in Western New York. U.S. Geological Survey Scientific Investigations Report 2006-5075, 14 pp. http://ny.water.usgs.gov/pubs/wri/ sir065075/sir2006-5075.pdf $\backslash$.

Mulvihill, C.I., A. Filopowicz, A. Coleman, and B.P. Baldigo, 2007. Regionalized Equations for Bankfull Discharge and Channel Characteristics of Streams in New York State - Hydrologic Regions 1 and 2 in the Adirondack Region of Northern New York. U.S. Geological Survey Scientific Investigations Report 2007-5189, 18 pp. http://pubs.usgs.gov/sir/2007/5189/pdf/ SIR2007-5189.pdf $\backslash$.

Osterkamp, W.R., R.E. Curtis, and H.G. Crowther, 1982. Sediment and Channel-Geometry Investigations for the Kansas River Bank Stabilization Study, Kansas, Nebraska, and Colorado. U.S. Geological Survey Open-File Report 81-128, 72 pp. http:// pubs.usgs.gov/of/1981/0128/report.pdf.

Padmanabhan, G. and B.H. Johnson, 2010. Regional Dimensionless Rating Curves to Estimate Design Flows and Stages. Journal of Spatial Hydrology 10:41-75.

Park, C.C., 1977. World-Wide Variations in Hydraulic Geometry Exponents of Stream Channels: An Analysis and Some Observations. Journal of Hydrology 33:133-146, doi: 10.1016/0022-1694 (77)90103-2.

Parola, A.C., K. Skinner, A.L. Wood-Curini, W.S. Vesely, C. Hansen, and M.S. Jones, 2005a. Bankfull Characteristics of Select Streams in the Four Rivers and Upper Cumberland River Basin Management Units. Project Final Report for Kentucky Division of Water NPS 99-12, University of Louisville Stream Institute, Louisville, Kentucky, 30 pp. http://water.ky.gov/permitting/Lists/ Working\%20in\%20Streams\%20and\%20Wetlands/Attachments/6/ FourRiversandUpperCumberland.pdf $\backslash$, accessed August 2013.

Parola, A.C., W.S. Vesely, M.A. Croasdaile, and C. Hansen, 2007. Geomorphic Characteristics of Streams in the Bluegrass Physiographic Region of Kentucky. Project Final Report for Kentucky Division of Water NPS 02-05, University of Louisville Stream Institute, Louisville, Kentucky, 101 pp. http://water.ky.gov/ permitting/Lists/Working\%20in\%20Streams\%20and\%20Wetlands/ Attachments/8/Bluegrassstreamsreport.pdf $\backslash$, accessed August 2013.

Parola, A.C., W.S. Vesely, A.L. Wood-Curini, D.J. Hagerty, M.N. French, D.K. Thaemert, and M.S. Jones, 2005b. Geomorphic Characteristics of Streams in the Mississippi Embayment Physiographic Region of Kentucky. Project Final Report for Kentucky Division of Water NPS 99-30, University of Louisville Stream 
Institute, Louisville, Kentucky, 49 pp. http://water.ky.gov/per mitting/Lists/Working\%20in\%20Streams\%20and\%20Wetlands/ Attachments/7/MississippitEmbayment.pdf $\backslash$, accessed August 2013.

Parrett, C., R.J. Omang, and J.A. Hull, 1983. Mean Annual Runoff and Peak Flow Estimates Based on Channel Geometry of Streams in Northeastern and Western Montana. U.S. Geological Survey Water-Resources Investigations Report 83-4046, 53 pp. http://www.dnrc.mt.gov/wrd/water_rts/appro_rules_ref/irrigation_ practices/c-04_neast_western.pdf.

Powell, R.O., S.J. Miller, B.E. Westergard, C.I. Mulvihill, B.P. Baldigo, A.S. Gallagher, and R.R. Starr, 2004. Guidelines for Surveying Bankfull Channel Geometry and Developing Regional Hydraulic-Geometry Relations for Streams of New York State. U.S. Geological Survey Open-File Report 03-92, 20 pp. http:// ny.water.usgs.gov/pubs/of/of03092/of03-092.pdf \.

Pruitt, B.A., 2001. Hydrologic and Soil Conditions across Hydrogeomorphic Settings. Ph.D. Dissertation, University of Georgia, Athens, Georgia.

Pugh, A., T. Garday, and R. Redman, 2008. Geomorphic Characterization of the Middle Fork Saline River: Garland, Perry, and Saline Counties, Arkansas. U.S. Geological Survey Scientific Investigations Report 2007-5152, 65 pp. http://pubs.usgs.gov/sir/ 2007/5152/pdf/SIR2007-5152.pdf \.

Rachol, C.M. and K. Boley-Morse, 2009. Estimated Bankfull Discharge for Selected Michigan Rivers and Regional Hydraulic Geometry Curves for Estimating Bankfull Characteristics in Southern Michigan Rivers. U.S. Geological Survey Scientific Investigations Report 2009-5133, 300 pp. http://pubs.usgs.gov/ $\operatorname{sir} / 2009 / 5133 /$.

Rosgen, D.L., 1996. Applied River Morphology. Wildland Hydrology Books, Pagosa Springs, Colorado, ISBN-13: 978-0965328906.

Sherwood, J. and C. Huitger, 2005. Bankfull Characteristics of Ohio Streams and Their Relation to Peak Streamflows. U.S. Geological Survey Scientific Investigations Report 2005-5153, 38 pp. http://pubs.usgs.gov/sir/2005/5153/pdf/Bankfull_book.pdf $\backslash$.

Simon, A., W. Dickerson, and A. Heins, 2004. Suspended-Sediment Transport Rates at the 1.5-Year Recurrence Interval for Ecoregions of the United States: Transport Conditions at the Bankfull and Effective Discharge? Geomorphology 58:243-262, doi: 10.1016/j.geomorph.2003.07.003.

Smith, D.P. and L. Turrini-Smith, 1999. Western Tennessee Fluvial Geomorphic Regional Curves. Report submitted to Water Management Division, United States Environment Protection Agency, Region IV, 38 pp. http://hydro.csumb.edu/Doug/html/ tn_reg_crv_1999.pdf.

Splinter, D.K., D.C. Dauwalter, R.A. Marston, and W.L. Fisher, 2010. Ecoregions and Stream Morphology in Eastern Oklahoma. Geomorphology 122:117-128, doi: 10.1016/j.geomorph.2010.06.004.

Sweet, W.V. and J.W. Geratz, 2003. Bankfull Hydraulic Geometry Relationships and Recurrence Intervals for North Carolina's Coastal Plain. Journal of the American Water Resources Association 39(4):861-871, doi: 10.1111/j.1752-1688.2003.tb04411.x.

USDA-NRCS, 2007. National Engineering Handbook Technical Supplement 5 Developing Regional Relationships for Bankfull Discharge Using Bankfull Indices, Washington, D.C., 9 pp.

Vesely, W.S., A.C. Parola, C. Hansen, and M.S. Jones, 2008. Geomorphic Characteristics of Streams in the Eastern Kentucky Coal Field Physiographic Region of Kentucky. Project Final Report for Kentucky Division of Water NPS 01-08, University of Louisville Stream Institute, Louisville, Kentucky, 27 pp. http:// water.ky.gov/permitting/Lists/Working\%20in\%20Streams\%20and $\% 20$ Wetlands/Attachments/9/EasternKYCoalfields.pdf $\backslash$.

Westergard, B.E., C.I. Mulvihill, A.G. Ernst, and B.P. Baldigo, 2005. Regionalized Equations for Bankfull-Discharge and Channel Characteristics of Streams in New York State: Hydrologic Region 5 in Central New York. U.S. Geological Survey Scientific
Investigations Report 2004-5247, 16 pp. http://ny.water.usgs. gov/pubs/wri/sir045247/sir2004-5247.pdf \.

White, K.E., 2001. Regional Curve Development and Selection of a Reference Reach in the Non-Urban, Lowland Sections of the Piedmont Physiographic Province, Pennsylvania and Maryland. U.S. Geological Survey Water-Resources Investigations Report 014146, 20 pp. http://pa.water.usgs.gov/reports/wrir01-4146.pdf \.

Wilkerson, G.V., 2008. Improved Bankfull Discharge Prediction Using 2-Year Recurrence-Period Discharge. Journal of the American Water Resources Association 44(1):243-258, doi: 10.1111/j.1752-1688.2007.00151.x.

Wilkerson, G.V., D.R. Kandel, L.A. Perg, W.E. Dietrich, P.R. Wilcock, and M.R. Whiles, 2014. Continental-Scale Relationship between Bankfull Width and Drainage Area for Single-Thread Alluvial Channels. Water Resources Research 50:919-936, doi: 10.1002/2013WR013916.

Williams, G.P., 1978. Bank-Full Discharge of Rivers. Water Resources Research 14(6):1141-1154, doi: 10.1029/WR014i006 p01141. 
SUPPLEMENT 1: Regression equations and standard errors of intercept $\left(\mathrm{SE}_{\mathrm{I}}\right)$ and slope $\left(\mathrm{SE}_{\mathrm{S}}\right)$ for the Physiographic Divisions and Provinces

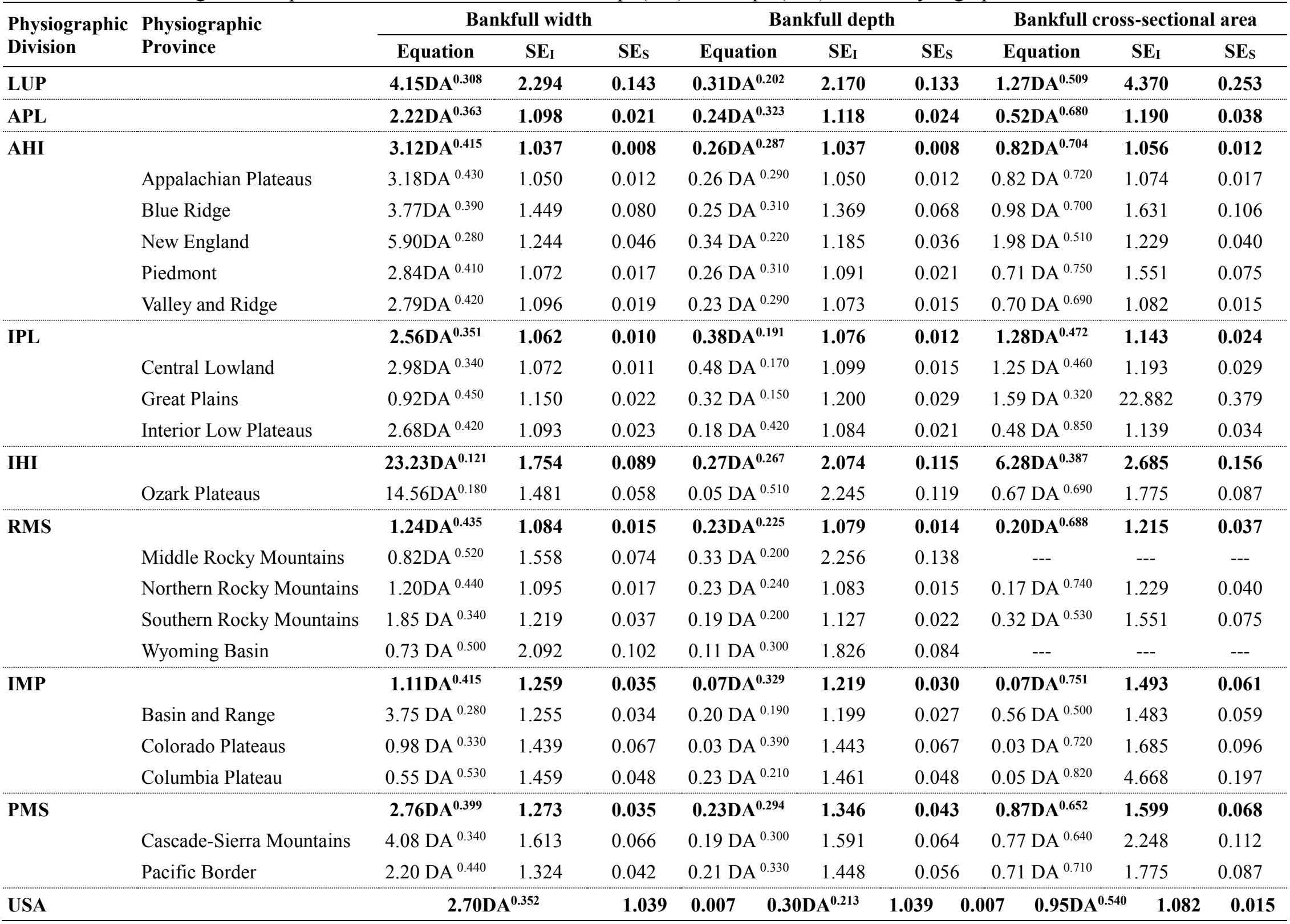



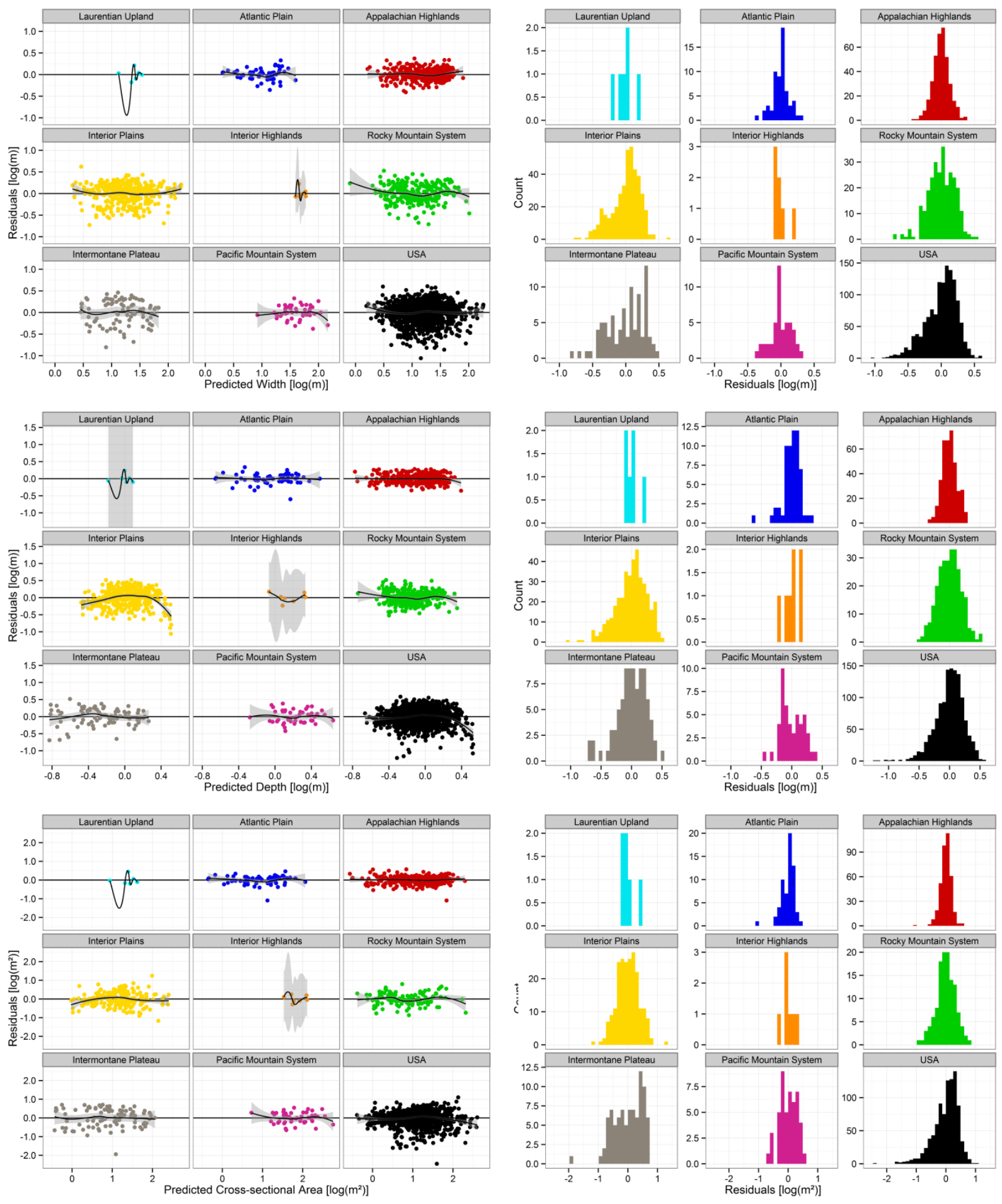

SUPPLEMENT 2. Residuals (predicted - observed) and their distributions for bankfull width (top), depth (middle) and cross-sectional area (bottom) per Physiographic Division (black lines = LOESS fit to residuals, grey shading $=95 \%$ confidence interval). 

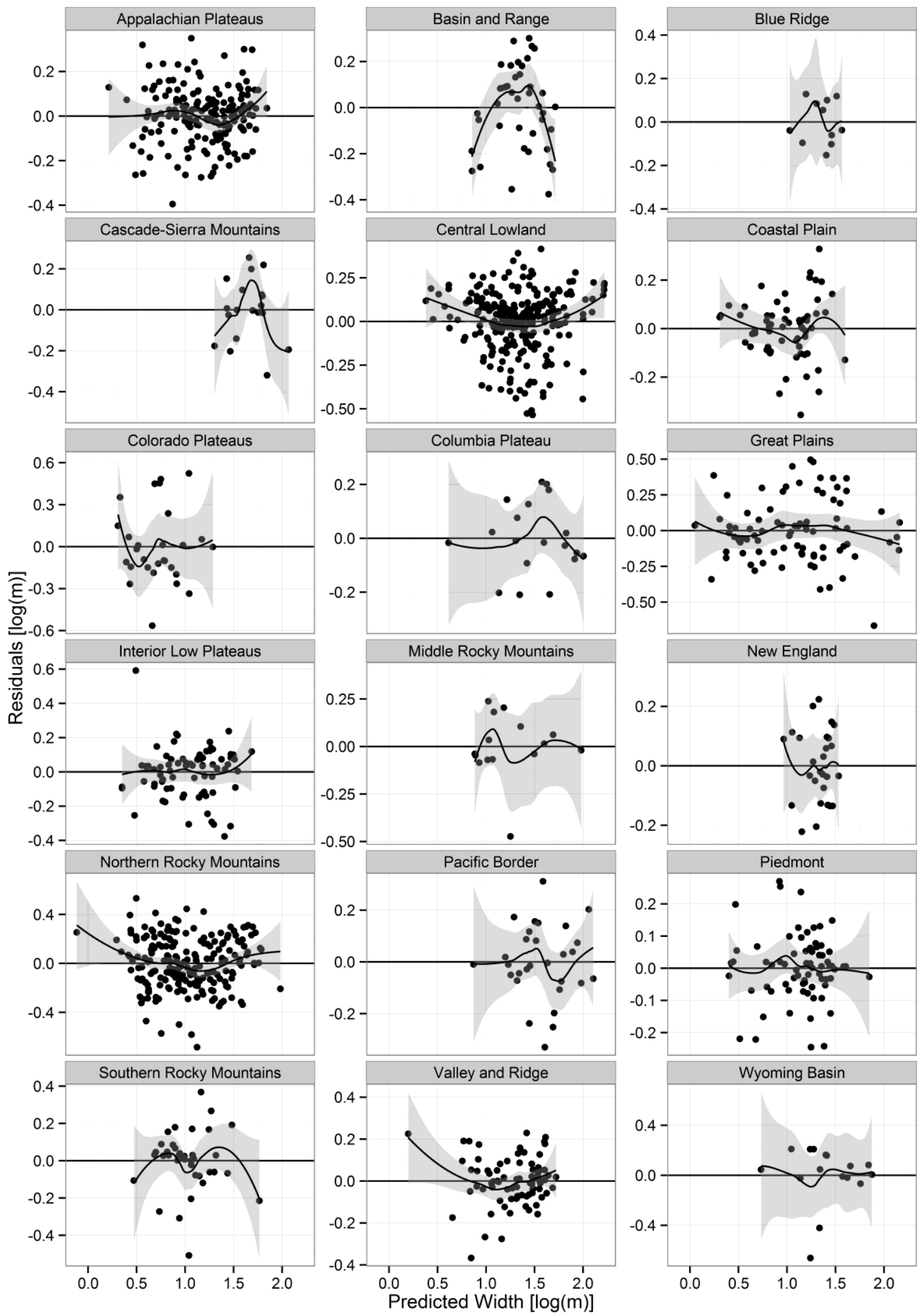

SUPPLEMENT 3. Residuals plot for the regression model predicting bankfull width at province level (black lines $=$ LOESS fit to residuals, grey shading $=95 \%$ confidence interval). 


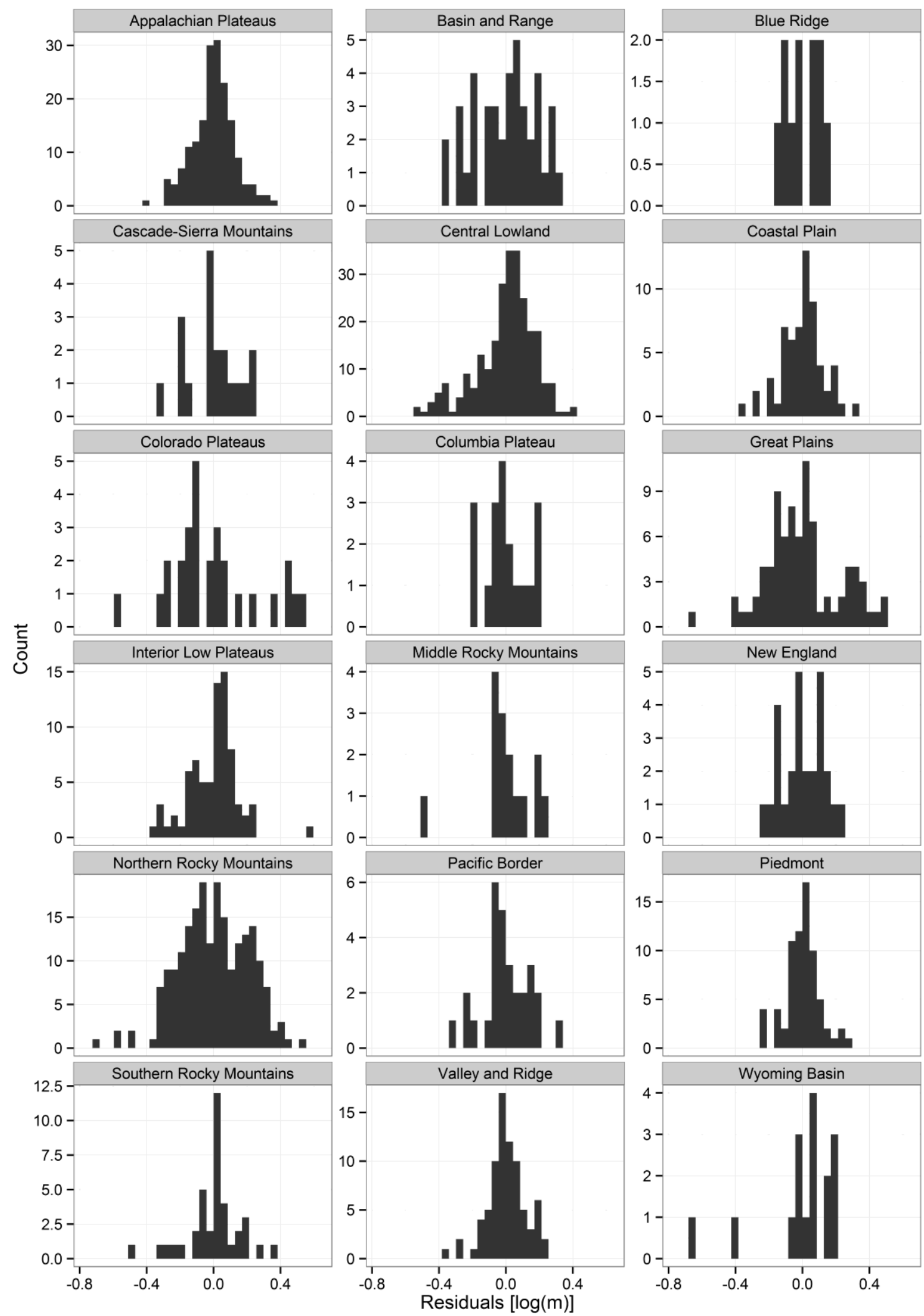

SUPPLEMENT 4. Frequency distribution of residuals for the regression model predicting bankfull width at province level. 

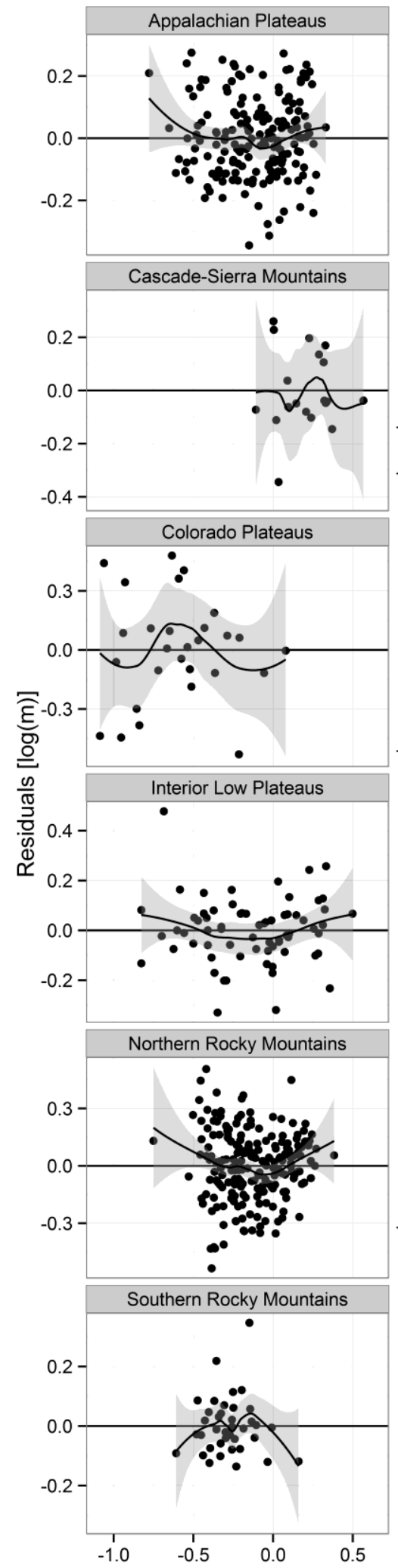
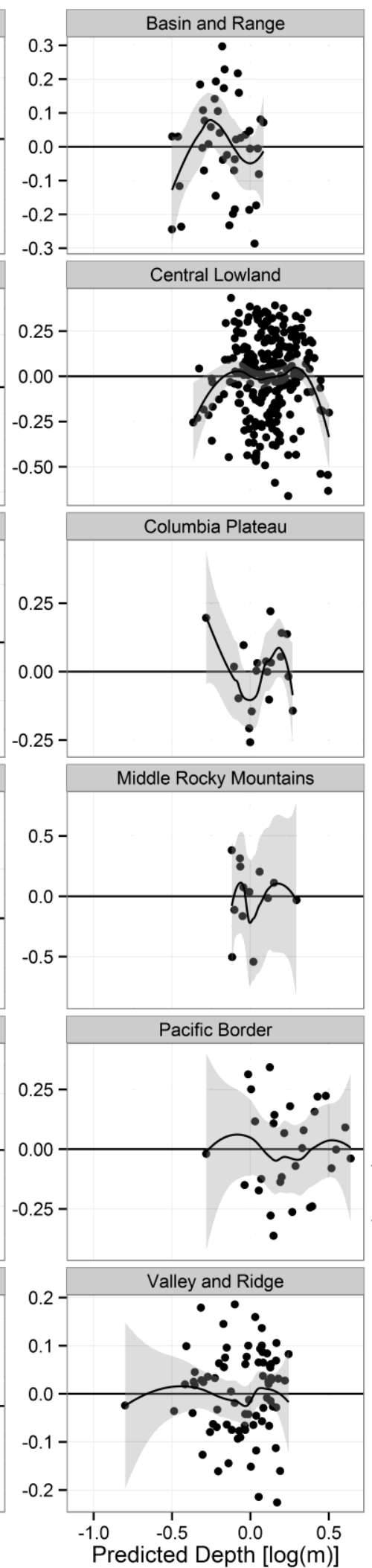
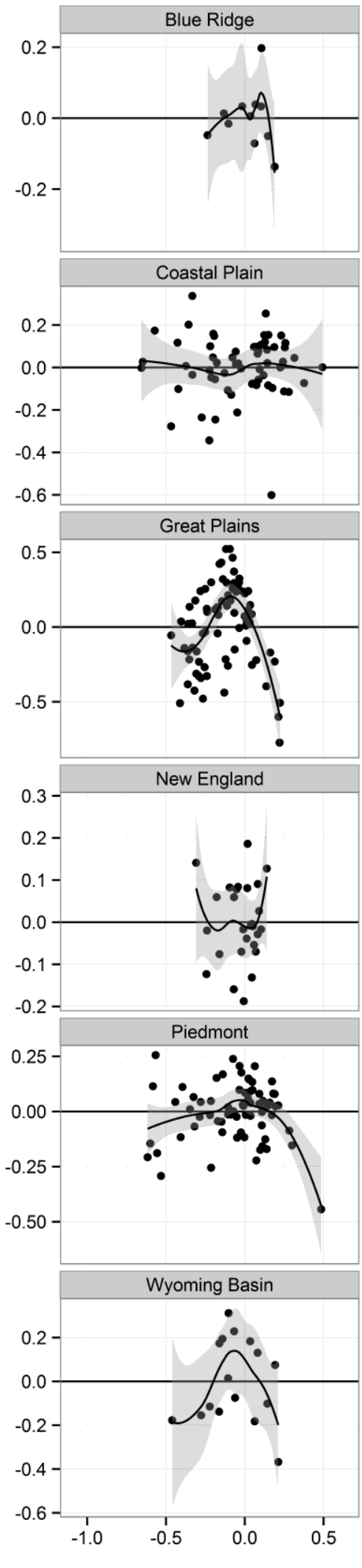

SUPPLEMENT 5. Residuals plot for the regression model predicting bankfull depth at province level (black lines $=$ LOESS fit to residuals, grey shading $=95 \%$ confidence interval). 


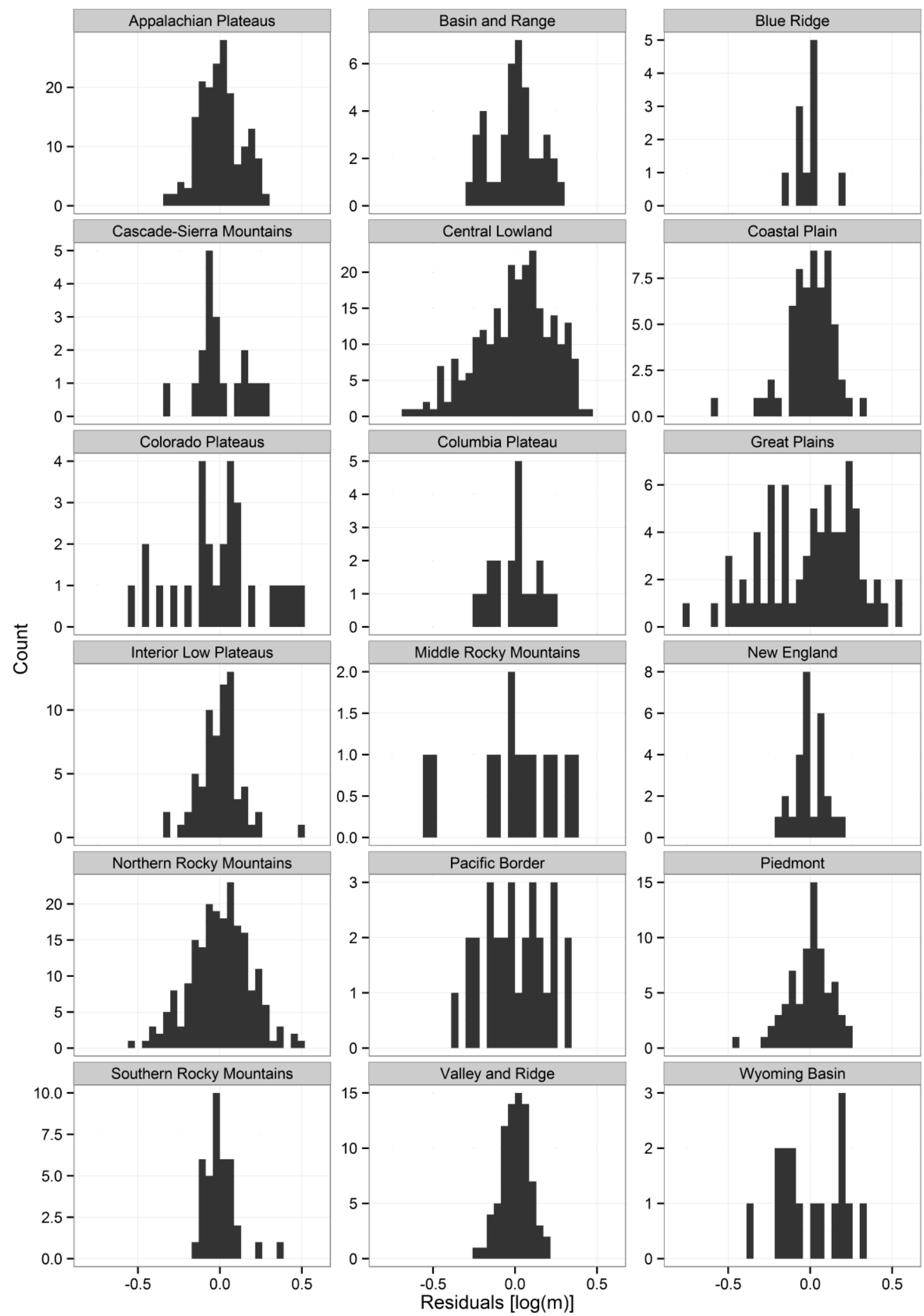

SUPPLEMENT 6. Frequency distribution of residuals for the regression model predicting bankfull depth at province level. 


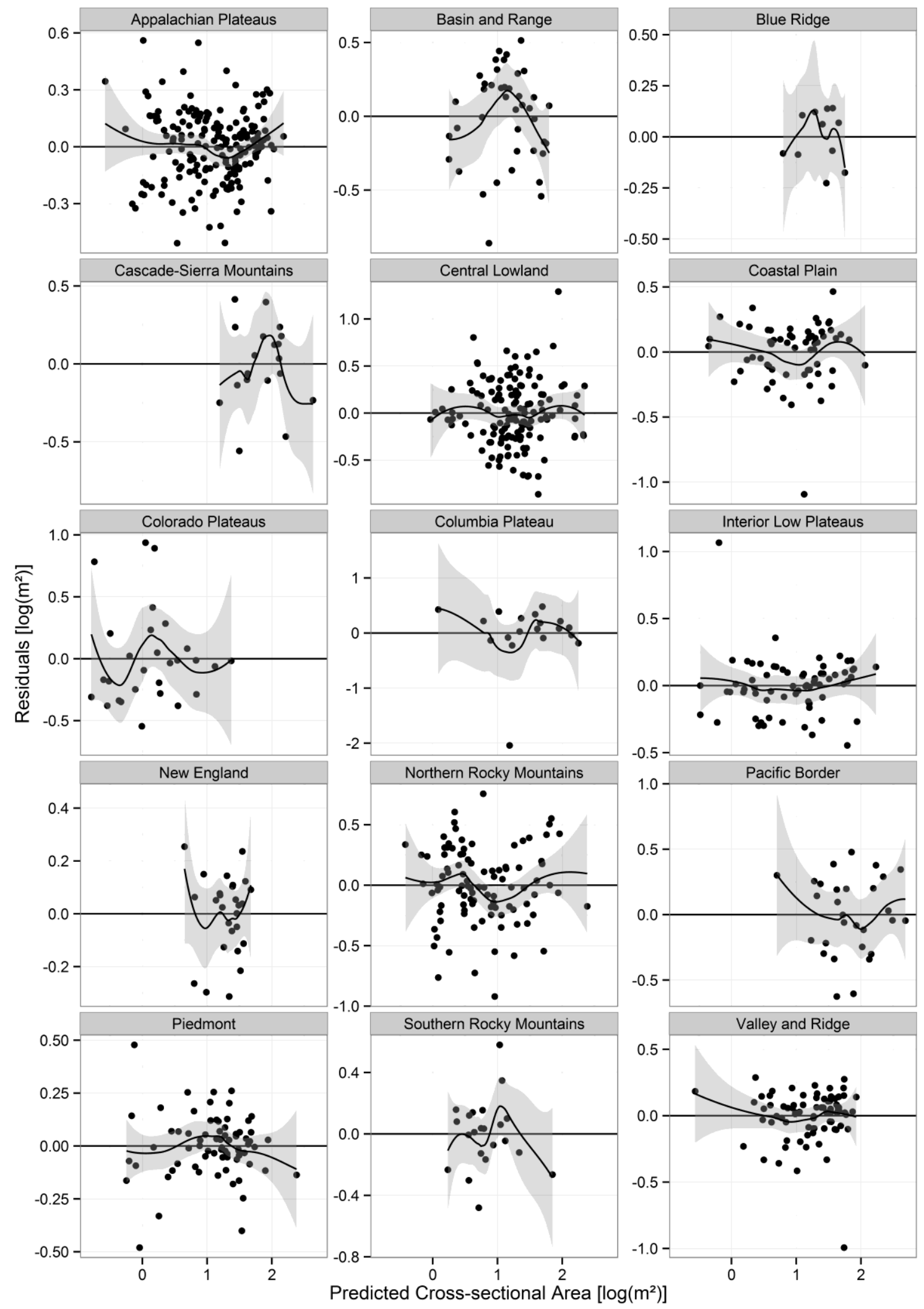

SUPPLEMENT 7. Residuals plot for the regression model predicting bankfull cross-sectional area at province level (black lines $=$ LOESS fit to residuals, grey shading $=95 \%$ confidence interval). 


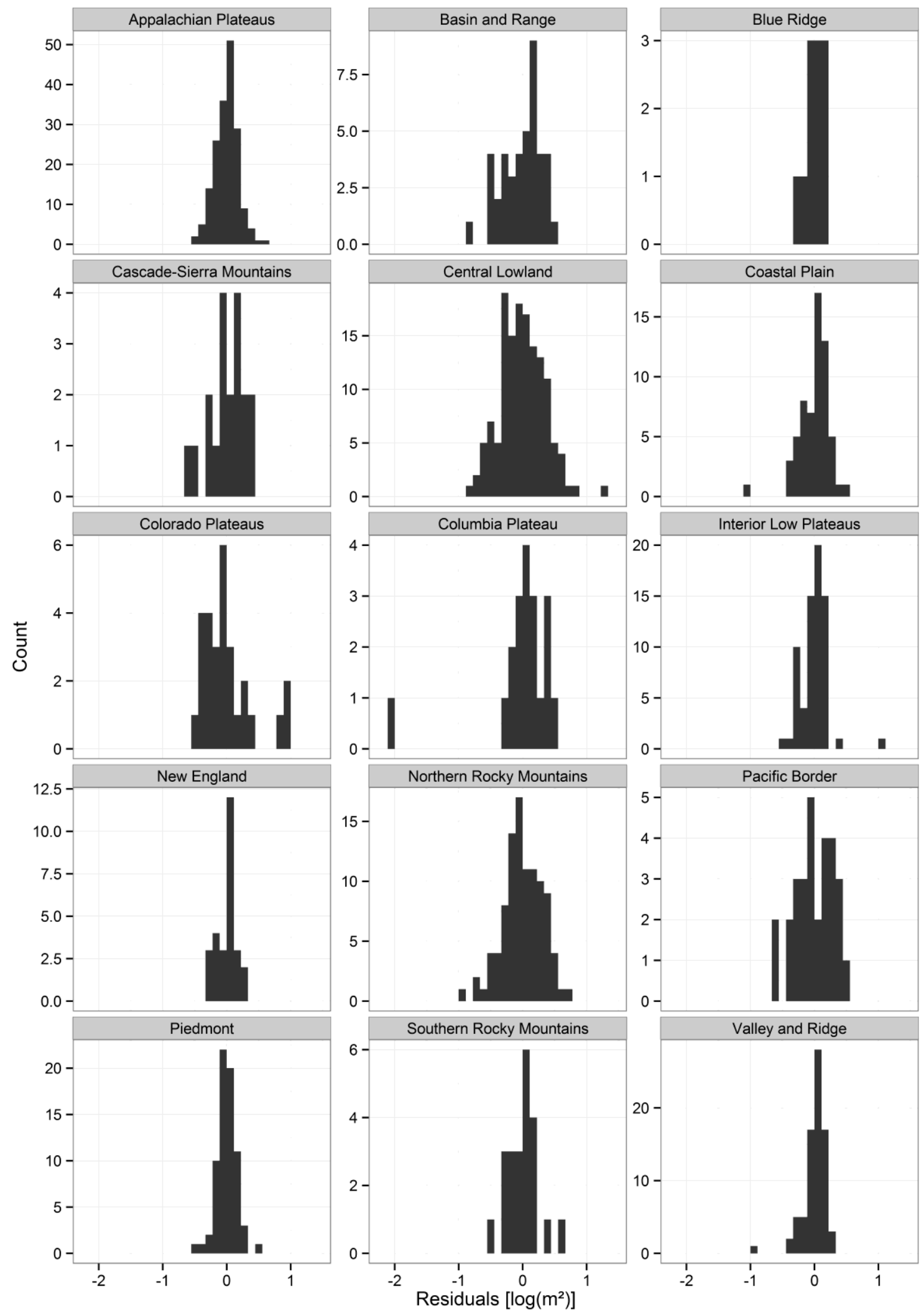

SUPPLEMENT 8. Frequency distribution of residuals for the regression model predicting bankfull crosssectional area at province level. 